\title{
Variation in Breton word stress: new speakers and the influence of French
}

\begin{abstract}
This paper investigates stress patterns in Breton across speakers of different ages and with different linguistic backgrounds. Centuries of contact with French have already led to French influence in Breton lexis, phonology and morphosyntax, and Breton's current status as an endangered minority language makes it vulnerable to further change. Additionally, younger 'new speakers' of Breton, who have acquired the language through Breton-medium education, are said to transfer features from French into their Breton (Madeg, 2010). Analysis of stress usage shows that older, traditional speakers use stress largely as expected, while there is a greater degree of interspeaker variation among younger, new speakers. These data are used to form a metrical analysis of stress in Breton, taking into account both lexical exceptions, loanwords and the variability of younger speakers. Rather than widespread transfer of French stress patterns into Breton, some younger speakers seem to be using two competing stress systems.
\end{abstract}

\section{Introduction}

\subsection{Background}

Discussions of Breton comparatively rarely choose to focus on metrical stress; perhaps because it is regarded as fairly regular, and therefore uninteresting. However, Breton's status as an endangered language makes an examination of its prosody more relevant: changes in obsolescing languages, often under influence from a neighbouring dominant language, are well-documented (see, e.g. Campbell \& Muntzel, 1989; Palosaari \& Campbell, 2011 inter alia), and affect all aspects of linguistic structure. This paper therefore examines metrical stress across two generations of Breton speakers separated by a gap in transmission.

Breton has seen a decline in speaker numbers over several centuries, but this accelerated in the late nineteenth and early twentieth centuries as a result of social and political pressure on the language, and following the Second World War, transmission of Breton from parent to child effectively ceased. Today there are thought to be around 200000 Breton speakers (Broudic, 2009), although this number is based on the last large-scale survey of the language in 2007, and the total number of speakers is likely to have decreased since then: at that time, around $47 \%$ of speakers were aged over 75 . However, there is a growing community of

\footnotetext{
I would like to thank the audiences at the $9^{\text {th }}$ Celtic Linguistics Conference, the $25^{\text {th }}$ Manchester Phonology Meeting, the $11^{\text {th }}$ International Symposium on Bilingualism and the $15^{\text {èmes }}$ Rencontres du Réseau Français de Phonologie, at which parts of this article were presented. Thanks are also due to Emily Darley for her help and advice in the revision of this article. I am very grateful to the Phonology editors and anonymous reviewers for their patience, careful and insightful comments, and helpful suggestions. Finally, I would like to thank the Breton speakers who participated in this study. All remaining errors are my own.
} 
younger speakers, who have learnt the language not at home, but through immersion or bilingual schooling. Breton immersion schooling began in the 1970s in the form of Diwan, which teaches entirely through the medium of Breton, and has led, along with other efforts, to a revitalisation of the language. The question then arises as to whether this gap in transmission, and long-term contact with French, is having an impact on the structure of the language itself, leading to language change.

Why choose metrical stress as a means of examining this potential language change? Stress is a highly salient feature of language, being a basic property of words, and there is a great deal of cross-linguistic variation in its acoustic and phonological realisation (van der Hulst, 1999). In some languages, stress plays a defining role; for example, in English stress is used to distinguish independent lexemes, such as ínvalid ${ }_{N}$ as opposed to inválid $_{A d j}$ (Frost, 2011). In others, such as French, word stress is much less important (Jun \& Fougeron, 2000), and there have been claims that native French speakers are 'deaf' to word stress (Dupoux et al., 1997; Dupoux et al., 2001; Peperkamp et al., 2010). Language contact can lead to change in any part of the grammar (Thomason \& Kaufman, 1988), and as Rice (2014) writes, prosody may be particularly vulnerable to change and spread in contact situations. Indeed, Matras (2009: 231) notes the susceptibility of stress to contact-induced change: 'Prosody seems to be more prone to cross-linguistic replication in contact situations than segmental phonology, with stress figuring in-between the two. The position of tone - which shows a high tendency toward areal clustering - may be considered somewhat problematic since it correlates strongly with the morphological typology of languages and so with internal diachronic developments. But tone too appears to be related to prosody (intonation and stress) in its contact susceptibility.' These facts are especially pertinent for Breton: all speakers of Breton are also fluent speakers of French, and there are no monolingual Breton speakers. Added to this, younger speakers of Breton come largely from French-speaking homes, although there is a very small but growing number of younger speakers whose parents also attended Bretonmedium education, and for whom Breton is (one of) the language(s) of the home (Le Pipec, 2013). Stress therefore seems an ideal means of exploring whether the prosody of Breton is changing as a result of its current sociolinguistic context.

\subsection{New speakers of Breton}

It is not only Breton's long history of contact with French and its decline over the $20^{\text {th }}$ century that make it vulnerable to language change. The gap in the transmission of the language, and the emergence of a new community of speakers, is also crucially important. The language of these younger Breton speakers is sometimes termed 'Neo-Breton' (Jones, 1998), and it is recognised that it differs from the traditional Breton of older native speakers. These younger speakers may be regarded as 'new speakers' of the language; a term which has become current in minority language studies and refers to speakers who have acquired a language outside the home, usually as part of efforts to revitalise the language (see, e.g. Costa, 2015; Jaffe, 2015; McLeod \& O'Rourke, 2015; Nance, 2015; Kasstan, 2017; Smith-Christmas et al., 
2018). It seeks to move away from traditional labels such as first- or second-language speaker, learner, native or non-native speaker (Nance, 2015), since the lines between these categories can become blurred in the minority-language context, and new speakers are often not regarded as 'authentic' or 'legitimate' speakers by the community or indeed the wider linguistic literature (Hornsby, 2005; McEwan-Fujita, 2010; Adkins, 2013; Hornsby, 2014).

New speakers of Breton are unlikely to have parents who speak the language: '[There is] a discernible trend among an increasing number of Breton speakers to attain speakerhood other than by means of intergenerational transmission' (Hornsby, 2015: 38). They may, however, have had input from other, usually older, family members, such as grandparents (Jouitteau, 2018). A number of claims have been made regarding the ways in which NeoBreton differs from 'traditional' Breton (Hornsby, 2005). These include: an avoidance of French loanwords and a preference for more 'Celtic-sounding' neologisms (Jones, 1995); French influence in the syntax, resulting in a generalisation of subject-initial word order over the range of word order options available in Breton (McDonald, 1989); loss of or confusion over the mutation system (Dressler, 1972); and loss of morphological distinctions such as the different forms of bezañ 'to be' (Hewitt, 1977). Neo-Breton is criticised by native speakers for not being 'real' or 'authentic' (Hornsby, 2014); Avezard (1999) writes that for many speakers, it is simply not 'du vrai breton'. Recent research, however, has begun to investigate what exactly characterises Neo-Breton, and to question some of these claims: for example, Kennard \& Lahiri (2017) find that verbal mutation is alive and well amongst younger adult Breton speakers, though it may be difficult for children to acquire, while Davies-Deacon (2017) shows that younger speakers do use French loanwords, and their preference for Celtic neologisms is much less than had been thought. Understanding what Neo-Breton is like and why it "sounds different" from traditional Breton is therefore a key issue in current research.

\subsection{Stress in Breton}

Crucial to an understanding of stress patterns in Breton is an appreciation of the regional differences that separate the different dialects. Breton has four main dialects, of which three, Kerneveg, Leoneg and Tregerieg are fairly similar to one another, while the fourth, Gwenedeg, differs more extensively. ${ }^{1}$ The first three dialects are therefore normally grouped together, and referred to as KLT, while Gwenedeg, spoken in the south-eastern part of Brittany, may be treated separately (see map in Figure 2). Naturally, there are many sub-dialects and intermediate varieties, but in terms of stress, the division between KLT and Gwenedeg is particularly noticeable: in KLT stress generally falls on the penultimate syllable, while in Gwenedeg it tends to be on the final syllable (see, e.g. Hemon, 1941; Jackson, 1967; Press, 2009). Indeed, Falc'hun (1947) writes that Gwenedeg is primarily distinguished from KLT on the basis of its stress pattern. There is also a transitional zone between Gwenedeg and KLT

\footnotetext{
${ }^{1}$ Some works refer to the dialects by their French names: cornouaillais, leonais, tregorrois, and vannetais.
} 
where stress is variable and may even fall on the antepenultimate syllable in some circumstances (see, e.g. Timm, 1984; Humphreys, 1995).

Figure 1. Location map of Brittany ${ }^{2}$

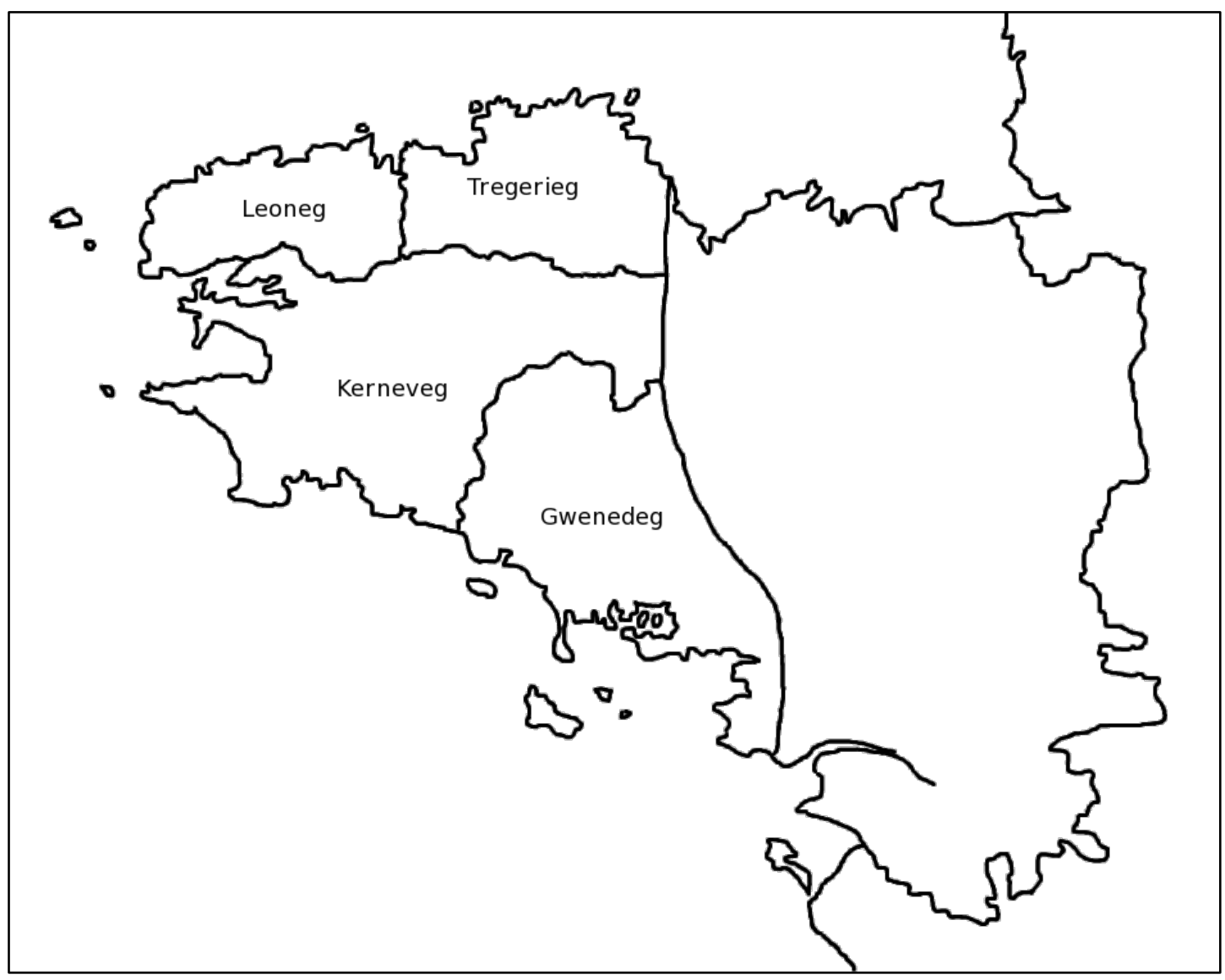

Figure 2. Map of Breton dialects

\footnotetext{
${ }^{2}$ Image copyright GwenofGwened, available through Wikimedia Commons (https://commons.wikimedia.org/wiki/File:Localisation Duch\%C3\%A9 de Bretagne.svg).
} 
Since the goal of this study is to examine the potential influence of French on Breton (and in particular the Breton of younger speakers), the focus is on the KLT dialects, where the main stress falls on the penultimate syllable, and there is a clear contrast with French phrase-final stress; for example: kador /'ka:dor/ 'chair', balafenn /ba'laf:en/ 'butterfly', fourchetezenn /furfe'te:zen/ 'fork'. ${ }^{3}$ Stress is said to be perceptually very salient: Hemon (1941: 92) writes that the 'accent tonique', or main stress, is very strongly marked in Breton, while Jackson (1967: 38) notes that the degree of intensity of the stressed syllable is 'comparatively strong'.

There are a small number of exceptions to the penultimate stress rule, where stress falls on the final syllable, even within the KLT dialects. Ternes (1992: 437) writes that Breton stress is marginally distinctive, there being no minimal pairs distinguished solely on the basis of stress, but adds that while final stress is marginal in Breton, 'it is considerably more important than in Welsh'. Desbordes (1983) presents a particularly comprehensive list of words with final stress, which includes some proper names (e.g. Katell /ka'tzl/), a small set of nouns (e.g. amann /ã'mãn:/ 'butter', gwinegr/gwi'nck(r)/ 'vinegar'), a single adjective (fallakr /fa'lak(r)/ 'wicked'), certain placenames, usually those formed from compounds where the second element is a monosyllable (e.g. Kastellin /kaste'lĩ:n/, Mespaol /mes'po:l/, Plouvorn /plu'vorn/), the first and second persons (singular and plural) of the prepositions gant 'with' and digant 'from' (e.g. ganin /gã' nĩ:n/ 'with me'), all of the situational forms of bezañ 'to be' (e.g. emañ /ẽ'mã/ 'he/she is'), and finally a large number of adverbs (e.g. abred /a'bre:t/

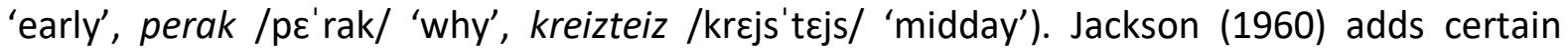
derived forms, such as verbal nouns (infinitives) ending in -aat (e.g. lakaat /la'ka:t/ 'to put'), and agentive nouns ending in -aer (e.g. pesketaer/peske'tacr/ 'fisherman').

Many of these final stress patterns have come about due to historical developments. Both the -aat and -aer endings are stressed due to an earlier contraction: they were originally two syllables, with the stress on the penult, but have now become a single long vowel or diphthong (Jackson, 1967). This can be observed for nouns such as pesketaer /peske'tacr/ 'fisherman': it is formed from the verbal noun pesketa /pes' ket:a/ 'to fish' and the agentive er, while the related noun pesketour /pes'ket:ur/ 'angler' has normal penultimate stress. Equally, the relatively large set of adverbs and prepositions with final stress were often originally formed from more than one element, such as abred /a'bre:t/ 'early' ( $<a$ 'of/from' + pred 'moment'). Stress falls on the right-most element of a compound, and so words which

\footnotetext{
${ }^{3}$ As there is a high degree of variation found across Breton dialects, a single word may have many different spoken interpretations. The majority of these do not interact with the stress pattern, and so in this article, Breton words are given with their Standard Breton pronunciation in the IPA (i.e. in citation form), unless an example is being given from a particular speaker, in which case the pronunciation as produced by that speaker is given. For clarity, stress is marked throughout, even though it is predictable (as will be discussed). There are also a number of different orthographies used for Breton; this article uses the the perunvan orthography, which is widely used by writers, and is taught in schools. An indication of the correspondence between Standard Breton and the orthography is additionally given in Appendix A.
} 
were historically compounds tend to have final stress when the rightmost element was monosyllabic. (e.g. kreizteiz /krejs'tzjs/ 'midday' < kreiz 'centre' + deiz 'day'; pemoc'h /pe'mo:x/ < penn-moc'h 'head of swine, pig') (Ternes, 1992). Of course, overall these exceptions form only a small proportion of the Breton lexicon, even though some words may be very frequently used.

Jackson (1960) discusses stress in loanwords from French. Breton has been borrowing from French for many centuries (Piette, 1973): French was the language of the ruling classes as far back as the thirteenth century (Moal, 2003), and was spoken in most large towns by the middle of the eighteenth century (Balcou \& Le Gallo, 1997), with the result that the two languages have coexisted for a long time. There are therefore, unsurprisingly, a large number of French loanwords in Breton, and Jackson writes that well-established loanwords are likely to assimilate to the Breton penultimate stress pattern, but more recent loans may not, retaining the final stress typical of French, e.g. bisiklet /bisi' klet/ 'bicycle', mekanig /mekã'nik/ 'machine' (< bicyclette, mécanique) (Jackson, 1960: 328). This therefore provides another source of word-final stress in Breton.

\subsubsection{Stress and syllable weight}

A number of accounts regarding the length of vowels in Breton note that long vowels are found in stressed syllables, but not unstressed syllables (e.g. Press, 1986; McKenna, 1988; Ternes, 1992). Jackson further notes that while in Leoneg unstressed vowels are not reduced, the reduction of unstressed vowels is common in Tregerieg (Jackson, 1967), and Sinou (1999) reports reduction of unstressed vowels in the Kerneveg dialect as spoken in Léchiagat. This sort of relationship between stress and segment duration is not unexpected, given that in many languages stressed syllables, and more usually stressed vowels, are longer than their unstressed counterparts (although there are of course exceptions where stressed vowels are not longer, one notable example being Welsh (Dogil \& Williams, 1999)). However, stress is clearly not the only factor that can affect segment length: there are other phonetic and phonological factors that may be relevant (for a summary, see, e.g. Himmelmann \& Ladd, 2008), and more importantly, languages may have phonemic length distinctions.

The question of phonemic segment length is particularly relevant in Breton, and most descriptions of Breton discuss this issue; in fact, it has been much more widely treated in the literature than stress. Breton is said to have a phonemic length distinction in vowels, as shown by pairs such as dall /dal/ 'blind' and dal /da:l/ 'take!'4 (Ternes, 1992: 430). Additionally, this vowel length contrast interacts with stress: unstressed vowels are always short, whereas stressed vowels may be long or short (Hemon, 1941; Press, 2009). In general, stressed vowels are long when they are word final, (e.g. ti /ti:/ 'house'), and when they are followed by what

\footnotetext{
${ }^{4}$ Second person singular imperative form.
} 
are termed in the literature lenis consonants (Press, 2009; Falc'hun 1951); they are short when followed by a consonant cluster (Hemon, 1941), or by a fortis consonant.

Although the fortis/lenis distinction has been widely discussed in the Breton literature (see, e.g. Hamp, 1951; Jackson, 1967; Anderson, 1981), it is not always well-defined, and the question of what the labels fortis and lenis refer to on a phonetic level is not always well addressed. Most accounts rely, at least to some extent, on Falc'hun's (1951) seminal study of phonetics in Leoneg Breton, in which he measures fortis and lenis consonants. For Falc'hun, the fundamental distinction in Breton consonants is that of fortis/lenis, while voicing and sonority play a subordinate role: for example, intervocalically, fortis obstruents are voiceless, while lenis obstruents are voiced. Falc'hun's measurements lead him to claim that fortis consonants are longer and have greater intensity than their lenis counterparts. His account is supported and extended by Carlyle (1988), who also examines a Leoneg variety of Breton. She confirms that, impressionistically at least, fortis consonants are longer and have greater intensity than lenis consonants, and investigates the association between tenseness and duration both in Breton and in other languages (mainly Zapotec and Jawoñ, as described in Jaeger (1983)), concluding that length is the prime factor in the distinction between fortis and lenis consonants. Many writers support this view, although it may not be expressed in precisely the same terms: Ternes (1992: 430), for example, writes that /n, I, r/ are slightly lengthened in intervocalic position after short stressed vowels, as in, for example tennañ

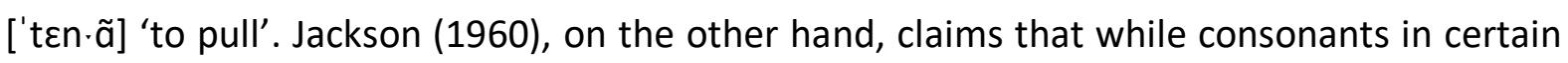
positions (e.g. after short stressed vowels) are a little longer than in other positions, these longer consonants cannot be considered geminates; however, the basis for this claim is unclear.

Carlyle's (1988) account crucially also presents the contrast between fortes and lenes from a phonological perspective, noting that they are structurally different. In her view, fortis consonants are analogous to geminates, in that they have inherent weight. Carlyle draws on data from Zapotec to explain this, showing that Zapotec fortes derive from consonant clusters whereby the two elements of the cluster are in the coda and onset of two adjacent syllables. In Breton, fortis obstruents are additionally voiceless, while lenis obstruents are voiced; Carlyle writes that this follows from their phonetic properties: a longer closure duration is more likely to result in devoicing.

Taking into account the nature of fortis and lenis consonants, then, the following relationships between stress and segment length begin to emerge for Breton. In monosyllables, vowels are long before lenis consonants, and short before fortis consonants. There is therefore a contrast between dal and dall, as mentioned above, or between kazh 'cat' /ka:s/ and kas 'send' /kas/. Breton has word-final devoicing, and so in final position, all obstruents are voiceless and the difference between voiced lenes and voiceless fortes is lost; however, the underlying difference in the consonants can be seen in the derived forms kazhig 'little cat' /'ka:zik/ and 
kasadur 'delivery' /ka'sa:dyr/. Carlyle additionally notes that in word-final position, the length contrast in fortes and lenes is lost.

As discussed above, in polysyllabic words, the norm in KLT Breton is for the penultimate syllable to be stressed. When the vowel in this syllable precedes a lenis consonant, it is long; when it precedes a fortis consonant, it is short. This pattern of vowel length in stressed syllables can be understood with reference to the structural difference between lenes and fortes discussed above. It seems that in Breton, stressed syllables must be bimoraic, and so in open syllables, the vowel is lengthened. When a vowel is followed by a fortis consonant, which has an underlying mora, the syllable is then bimoraic. When the stressed vowel is followed by a lenis consonant, it forms the onset of the following syllable, and does not add weight to the stressed syllable. Indeed, Falc'hun (1951), in his measurements of Breton segments, notes that stressed syllables appear to be of the same length, regardless of whether they be of the form VC: or V:C. This is therefore an instance of Open Syllable Lengthening, a phenomenon common across languages, and suggests that in fact vowel length is not phonemic in Breton, but rather follows from the phonemic distinction between fortis and lenis consonants.

This account of vowel length in Breton does not, at first glance, explain the pattern observed in monosyllables, where although vowels are long before lenes and short before fortes, in both cases there is a closed syllable, which ought therefore to be bimoraic without any additional lengthening of the vowel. Carlyle (1988) addresses this point by positing that the final consonant of the word is extrametrical, and therefore does not add weight to the syllable. In the case of lenis consonants, this comprises the whole consonant: monosyllables with final lenes behave like open syllables, and vowel lengthening therefore applies. In the case of final fortis consonants, only part of the consonant is extrametrical and so the word remains a single closed syllable.

(1) Extrametricality in monosyllables:

$\begin{array}{lll}\text { Underlying fortis/lenis contrast: } & \text { /dal/ } & \text { /dal:/ } \\ \text { Extrametricality: } & \text { da }<1> & \text { dal }<1> \\ \text { OSL; loss of consonantal length contrast: } & \text { [da:l] } & \text { [dal] }\end{array}$

It is worth noting that Carlyle (1988) proposes different analyses for sonorants and obstruents, claiming that fortis obstruents are entirely extrametrical, since they can form syllable onsets, and that in obstruent-final monosyllables, the lenis/fortis contrast does not result in a vowel length distinction. However, this appears to be based on her data from the particular variety of Leoneg she investigates, and does not necessarily seem to be true of Breton in general, where in many varieties there is a distinction between kazh and kas, as noted above. 


\subsection{Outline}

The use of stress by new speakers of Breton has been described in the literature, although perhaps to a lesser extent than some other features of Neo-Breton. The predominant or usual claim is that French stress patterns are being carried over into Breton by French-dominant younger speakers (e.g. Madeg, 2010), so that new speakers use final stress in Breton regardless of whether or not they come from the Gwened region (and indeed, use other features characteristic of Gwenedeg). In fact, the Breton of new speakers or L2 learners is sometimes disparagingly referred to as Roazhonég (Dressler, 1991), with the stress on the final syllable, meaning 'Breton as spoken in Rennes', a city known for its attempts to revive Breton, but where only French has been spoken for many centuries. However, as we have already seen, claims about Neo-Breton are not necessarily accurate, or at least, applicable to the whole population of new speakers. The aims of this paper are therefore threefold:

1. To establish how Breton speakers in the Kerneveg dialect region use stress, including an examination of its acoustic properties;

2. To compare the use of stress among new speakers, and discover to what extent influence from French is apparent in their stress patterns;

3. To use these data to reach a possible metrical analysis of stress in Breton, taking into account both traditional and new speakers.

The paper is structured as follows: the fieldwork methodology is presented in Section 2, followed by an examination of stress usage in Section 3. Section 4 gives details of the acoustic properties of stress, and the final discussion follows in Section 5.

\section{Fieldwork methodology}

To investigate how Breton speakers use stress, fieldwork was undertaken in south west Brittany in June 2016, in the area surrounding Quimper (the main administrative centre), and as far east as the area surrounding Châteauneuf-du-Faou. All of the fieldwork sites fall within the Kerneveg dialect region; the aim was to minimise regional variation as far as possible, and in particular to avoid speakers who might have been influenced by the Breton spoken in the Gwened region or the transitional zone, since this could potentially introduce additional variation.

\subsection{Speakers}

Two groups of speakers took part in the study: first, 11 older speakers aged 57-83 (mean age: 73.4; 3 men, 8 women), and secondly, 9 younger speakers aged 27-52 (mean age: 38.3; 5 men, 3 women). Speakers were recruited using the 'friend of a friend' model (Milroy, 1980), which is an effective method for small language communities (Ball \& Müller, 1992; Jones, 1998). The older speakers in the study all grew up speaking Breton at home with their families, 
and thus acquired Breton as a first language. Several of them spoke no French before they went to school (aged about six), and most cannot read or write Breton. The majority of the older speakers continue to live in the isolated rural locations where they grew up, and they may speak Breton with a spouse, close friends and neighbours, and family of the same generation.

The younger speakers are all 'new speakers' of Breton; that is, they come largely from Frenchspeaking homes, and acquired Breton through schooling; usually Diwan, but also bilingual streams, university courses, and Breton-language instruction outside the school environment. A few heard Breton being spoken by older relatives, and later, as older children or teenagers, were motivated to acquire more than a simply passive understanding of the language. They are all now in employment where they use mainly Breton on a daily basis: in education, the media, or cultural organisations.

\subsection{Elicitation}

The goal was to elicit 30 disyllabic and 30 trisyllabic nouns from each speaker. Speakers were shown a series of images on a (laptop) computer screen, and asked to name the items in the images in Breton. Participants' responses were audio-recorded, and their stress patterns were analysed afterwards. This elicitation method was chosen for a number of reasons: first, it avoided the possibility of additional influence from French that translation might have introduced (see, e.g. Lüpke, 2009). Secondly, it was a method that could be used with both groups of speakers without any of the issues that reading a word-list might have involved. As mentioned above, most of the older speakers are unable to read or write Breton with any fluency, and so a task involving reading would be problematic. In addition, using pictures allowed speakers to choose the word most natural to them for the item in question: there is a lot of lexical variation both between traditional and 'neo' Breton, and within traditional Breton itself. For example, the most commonly used word for 'butterfly' is balafenn /ba'laf:cn/, but the French loanword papilhon /pa'pi:/on/ and the regional lexemes barbellig /bar'bel:ik/ and meleneg /mع'le:nek/ were also used. This variation was in one sense a hindrance to the analysis, since it meant that not only were the words elicited not necessarily directly comparable from speaker to speaker, but also the number of words in each of the two categories (disyllabic and trisyllabic) varied from speaker to speaker much more than it would otherwise have done. However, since the goal was to elicit speech that was as natural as possible, given the constraints of the fieldwork task, asking speakers to produce words that were not in their own vocabularies would have been counter-productive, even if reading from a list had been possible.

The analysis was performed perceptually: the researcher (a native English speaker) listened to each individual word carefully and noted the stress patterns; the words were then checked by a second listener (a native German speaker), and any discrepancies were revisited. Any unclear examples were omitted from the analysis. The acoustic cues to stress in Breton will 
be discussed in Section 4, but it is worth noting at this point that the listeners were aided in their task by the fact that unstressed vowels in Breton tend to be reduced, particularly word finally, particularly among older speakers, and particularly in this part of Brittany. Local varieties of Kerneveg naturally differ somewhat from Standard Breton, which is more closely based on Leoneg, particularly in lexis, phonology and morphophonology; however, few of these differences are relevant to the stress pattern, which follows the expected penultimate stress found in all KLT varieties. The most pertinent point of variation concerns unstressed syllables, which tend to undergo reduction or even, in longer words, deletion. Thus, bolotenn 'ball' would be rendered /bo'lot:عn/ in Standard Breton, but /bo'lot:ən/ or even /bo'lot:n/ in Kerneveg. This variation only affects the older adults in this study, and as it has no impact on which syllable receives the main stress, it not discussed further in Section 3, but is addressed in the acoustic analysis in Section 4. Both listeners in this study had linguistic and phonetic training, but neither was a native Breton speaker; however, this methodology is commonly used in prosodic descriptions of languages (see, e.g. Himmelmann \& Ladd, 2008).

One final limitation of the elicitation method used is that the words were produced in isolation, a context which has been identified as problematic in some cases in the literature, since words uttered in isolation act as phrases in their own right, which may in turn give misleading cues to stress (Gordon, 2011). However, the use of a carrier sentence for each word might have been even more problematic in Breton: aside from the difficulties of suggesting a carrier sentence to older speakers, who might prefer alternative phrasing from that used by younger speakers, word order in Breton is both highly flexible, and variable across the different groups of speakers (Kennard, 2014). For example, speakers might choose to place new information in initial position, or might prefer subject-initial word order, or something else entirely. In light of this, it was decided to limit the potential for variation by eliciting words in isolation, to obtain more comparable data.

\section{Findings: use of stress}

\subsection{Disyllables}

\subsubsection{Exceptions to penultimate stress: word-final exceptions}

Two of the words included in the disyllabic word set were known to be 'exceptions' to the penultimate stress pattern, instead taking word-final stress: amann /ã'mãn:/ 'butter' and pemoc'h /pe'mo:x/ 'pig'. As such, it would be misleading to count them among the other disyllabic words when examining the stress patterns of the two groups of speakers; they are likely to disrupt the results, and will therefore be examined separately. As expected, most speakers do indeed use final stress in these words, as Figure 3 shows. 


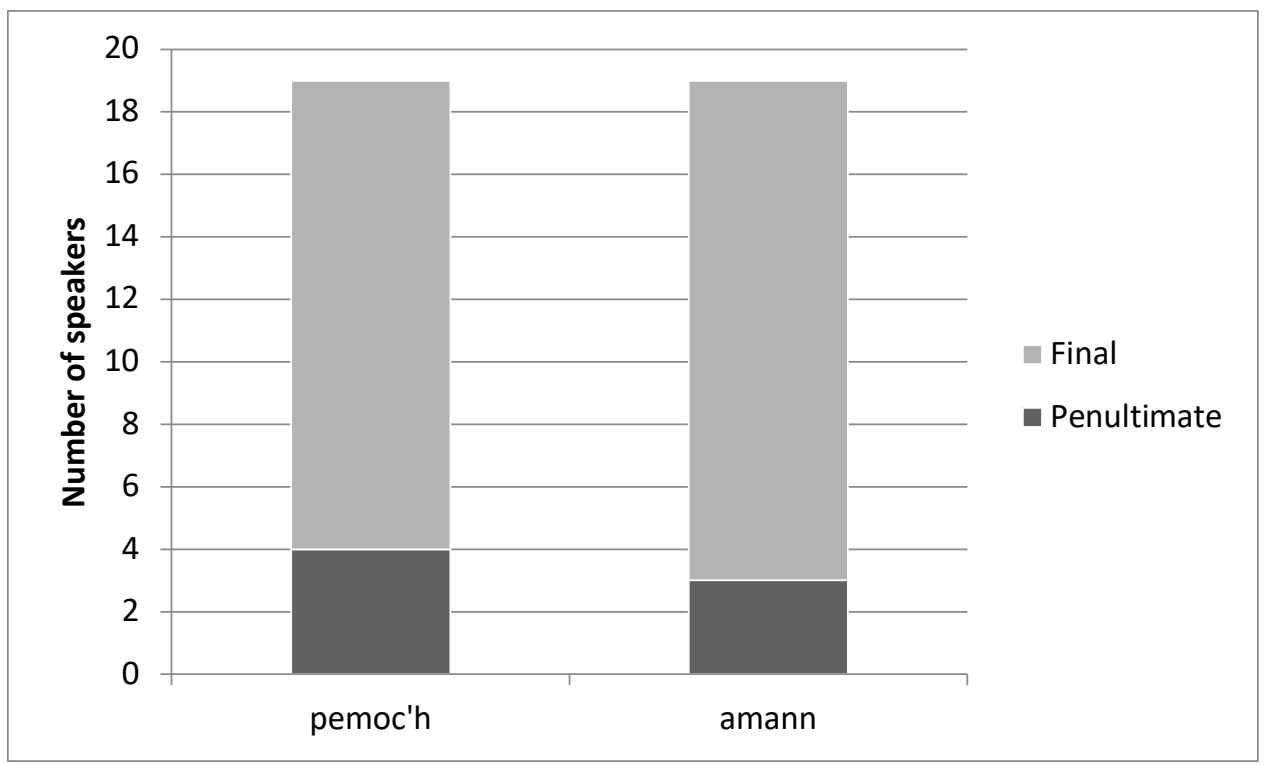

Figure 3. Stress patterns in pemoc' $h$ 'pig' and amann 'butter'

A few speakers use penultimate stress in one or both words, and details are given in Table 1.

Table 1. Details of speakers who use penultimate stress in the final-stress exceptions pemoc' $h$ 'pig' and amann 'butter'

\begin{tabular}{lll}
\hline Speaker & pemoc'h & amann \\
\hline HY & Final & Penultimate \\
IQ & Penultimate & Penultimate \\
MZ & Penultimate & Penultimate \\
XX & Penultimate & Final \\
ZI & Penultimate & Final \\
\hline
\end{tabular}

Only one of these speakers (ZI) is part of the older group, and it therefore seems likely that this is an overgeneralisation of the prevailing penultimate stress pattern, extended to include these historically word-final exceptions.

It was also found that the loanword ananas 'pineapple' was given final stress by all speakers who produced it (/ãnã'nas/), regardless of speaker group (14 speakers in total), and so this word is also excluded from the analysis of trisyllabic nouns to follow. The data in Figure 3 includes instances where speakers adapted the word to Breton morphological and wordformation processes, as in penn-ananas. Penn 'head' can also mean both 'tip, end (of)' and 'piece (of)', and acts as a type of singulative, meaning 'a single one'. It is most commonly associated with herds of animals (e.g. ur penn-deñved 'a (single) sheep'), but its use is quite productive, and it can be applied to other nouns as well (e.g. ur penn-ognon 'a (single) onion'). 


\subsubsection{Standard disyllabic nouns}

Turning now to the main set of disyllables, we find that the older speakers use largely the expected penultimate stress pattern ( $92.5 \%$ penultimate stress), which is to be expected from the descriptions of the language already discussed. This implies that there are few language attrition effects among the traditional speakers (see, e.g. Dressler, 1991) and confirms that speakers of the dialect Kerneveg do indeed use penultimate stress in the majority of nouns. The usage of the younger speakers is very similar, as Table 2 shows: penultimate stress is used in $90.6 \%$ of nouns, and a chi-squared test confirms that there is no significant difference between the two groups of speakers $\left(\chi^{2}=0.64 ; d f=1 ; p=0.43\right)$.

Table 2. Stress patterns in disyllables (raw frequencies and percentages; excludes 'known' exceptions)

\begin{tabular}{lllll}
\hline & Penultimate & & Final \\
\hline Older speakers & 235 & $92.5 \%$ & 19 & $7.5 \%$ \\
Younger speakers & 230 & $90.6 \%$ & 24 & $9.4 \%$ \\
\hline
\end{tabular}

Additionally, there is relatively little interspeaker variation in disyllables, and in each speaker group, there is a fairly narrow range of final stress frequencies, although this is greater among the younger speakers.

\subsection{Trisyllables}

Although there was no difference between the two groups of speakers in disyllables, the picture for trisyllables looks quite different (see Table 3). The older speakers, as expected, use predominantly penultimate stress $(90.1 \%)$, bringing their usage in trisyllables in line with that of disyllables. The younger speakers, however, use final stress much more with trisyllabic nouns, and a chi-squared test shows the difference between the groups to be significant $\left(\chi^{2}\right.$ $=21.28 ; \mathrm{df}=1 ; \mathrm{p}<0.00001$ ).

Table 3. Stress patterns in trisyllables (raw frequencies and percentages; 'known' exceptions excluded)

\begin{tabular}{lllll}
\hline & Penultimate & & Final \\
\hline Older speakers & 173 & $90.1 \%$ & 19 & $9.9 \%$ \\
Younger speakers & 163 & $72.1 \%$ & 63 & $27.9 \%$ \\
\hline
\end{tabular}

Looking at the data more closely, it quickly becomes apparent that there is much more interspeaker variation among the younger speakers than the older speakers, and more than was observed for disyllabic nouns. Stress usage among the older speakers seems to be reasonably consistent (here, there are no outliers), while there is much more variation among the younger speakers. Figure 4 provides more detail regarding the extent of variation in the data from the younger speakers. 


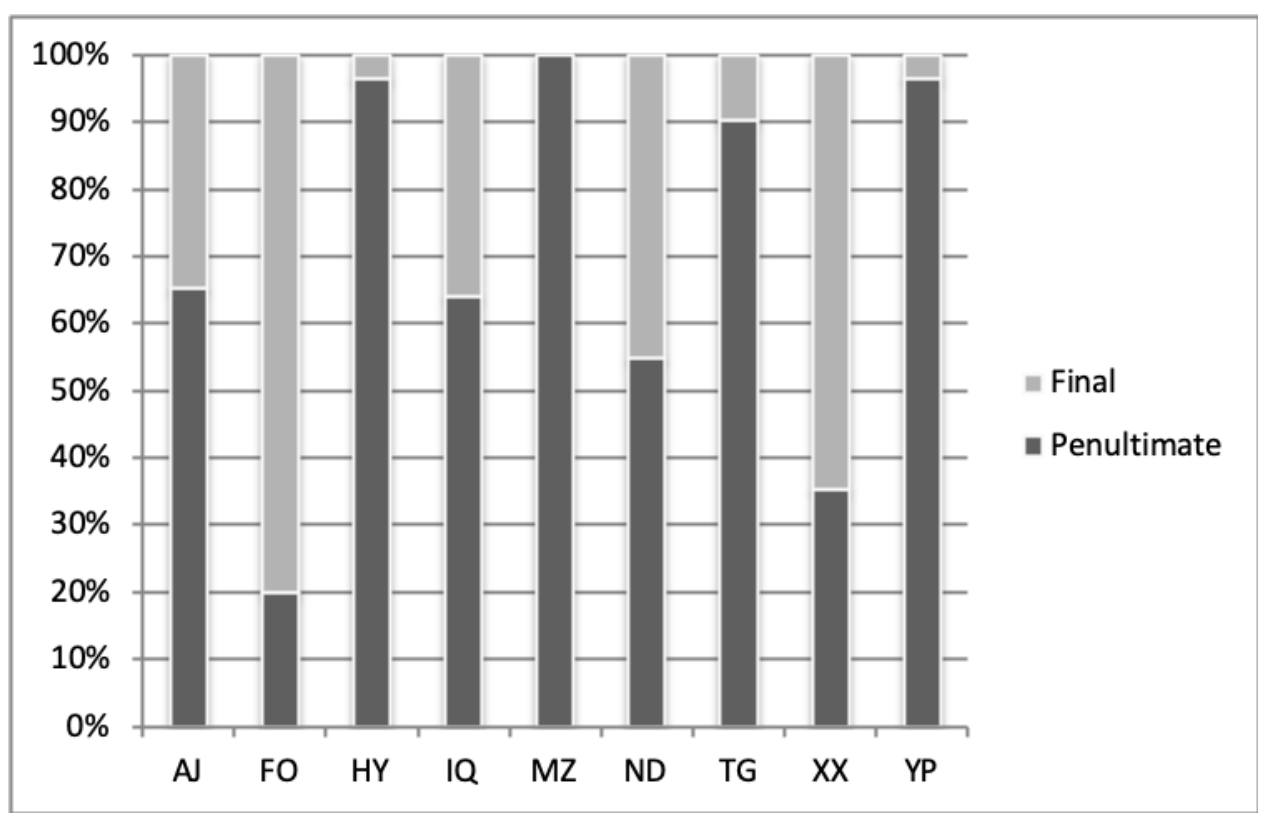

Figure 4. Younger speakers' use of stress in trisyllabic nouns

It is clear from this that some younger speakers (particularly FO and XX) use final stress to a much greater extent in trisyllabic nouns in comparison with disyllabic nouns; however, this is not true of other younger speakers (particularly HY, MZ, TG and YP), whose use of word stress is more similar to that of the older speakers; another three speakers (ND, IQ and AJ) fall somewhere in between. The discussion can now turn to the acoustic properties of Breton stress, and how they might fit into this picture of stress usage.

\section{Acoustic correlates of Breton stress}

There is relatively little discussion in the literature of how stress manifests itself in Breton, although, as noted above, it is said to be comparatively strongly marked (Hemon, 1941; Jackson, 1967). Ternes (1992) and Jackson (1967) also agree that stressed syllables have higher pitch than unstressed syllables, and Desbordes (1983: 112) writes that I'accent tonique se marque fortement en breton', possibly referring to increased intensity; this is supported by Sinou (1999). Although this is primarily a phonological rather than a phonetic study, the acoustic correlates of stress in Breton are naturally of interest, and important to the discussion of the data presented in Section 3. As de Lacy (2014: 185) writes, using acoustic information in the analysis of stress patterns is regarded as good practice: 'there is a consensus that a phonological description based on primary fieldwork should include information about the subjects (e.g. sex, age, perhaps native-speaker status), and that there should be at least some phonetic analysis'.

Gordon (2011) writes that there are three main acoustic properties used to signal stress: increased duration (length), greater intensity (loudness) and higher fundamental frequency (pitch). Languages differ in their relative reliance on these cues; for example, a language with phonemic length may rely less on increased duration as a maker of stress. Additionally, these 
acoustic cues to stress can be affected by a number of factors. High vowels, for example, have a naturally higher F0, and so may appear to be higher in pitch, but this is not necessarily connected with stress. Stress may also have a qualitative effect on syllables, besides changing the duration of segments. Stressed syllables often contain 'full' vowels, while unaccented syllables may contain 'reduced' vowels, or belong to a subset of the vowel system. This can form an important cue for listeners, as was the case in the analysis of the data in Section 3.

It is clear that there is the potential for a great deal of variation in the realisation of stress cross-linguistically. In Breton's closest living relative, Welsh, the acoustic realisation of stress is somewhat unusual, with vowels in stressed syllables being shorter, with lower amplitude and only very small changes in F0. Consonants that follow stressed vowels, on the other hand, are significantly longer than consonants following unstressed vowels. Dogil \& Williams (1999) report the results of experiments where Welsh and English speakers listened to a Welsh word list and made judgments about where the stress lay; unsurprisingly, the English monolinguals chose the syllables with the longest vowels, which were not regarded as stressed by native Welsh speakers. This highlights the importance of using language-specific data on stress in analysing stress patterns, and given that Breton is closely related to Welsh, it seems particularly important to investigate these properties thoroughly.

Acoustic measurements were taken for all the responses given in the fieldwork task. The individual segments of each word were labelled using the acoustic software Praat (Boersma \& Weenink, 2018), and measurements were taken of their duration, intensity and F0. ${ }^{5}$ Clearly, given that Breton has phonemic segment length, an examination of the acoustic differences between stressed and unstressed syllables needs to take this into account. Also of interest, given the findings in Section 3, is whether there are differences in the acoustic realisation of stress among the younger as opposed to the older speakers. The main questions that this acoustic analysis seeks to answer therefore as follows:

1. Do the younger speakers maintain the phonemic length distinction in fortis as opposed to lenis consonants? Do they lengthen vowels as a consequence of this?

2. In words with only short vowels, is the stressed vowel phonetically longer and more intense than the unstressed vowel(s)?

3. How do examples with perceptually final stress compare? What is the mean segment length?

The answers to these questions may shed additional light on the findings presented in Section 3.

As the study was designed to elicit speech that was as natural as possible, given the constraints of the fieldwork context, it was impossible to match various phonetic factors across words and across speakers, as would perhaps ordinarily be done in a primarily acoustic

\footnotetext{
${ }^{5}$ This was achieved using the Praatscript Get duration, pitch, intensity, formants (Le Grézause, 2018).
} 
study. For example, speakers produced a wide range of different vowels, the same word might show variation in vowel quality from one speaker to another, which in turn has an impact on the acoustic measurements. To give a concrete example, the word fourmaj might be produced with a final /a/, or with a final /ə/, depending on the speaker; /a/ is likely to be longer, and to have greater intensity, than /ə/. Equally, although all the words had two or three syllables, there was little consistency regarding their phonological structure: they might or might not begin or end with a consonant; most had one or more medial consonants, but this was not always the case, etc. Therefore, to achieve some level of consistency in the analysis, a subset of words was chosen, to fulfil the following criteria: (i) having the phonological structure CVCVC or CVCVCVC (no vowel-initial or vowel-final words); (ii) being used by most, if not all, of the speakers, across both groups. The counts for individual lexemes are lower for the trisyllabic nouns, but a greater number of distinct lexemes was included in the sample. The words included in the sample are given in Table 4. Looking specifically at the vowel measurements, words where the vowel was devoiced (e.g. before a voiceless stop), or where there was a syllabic nasal in place of a vowel, (e.g. ur berenn 'a pear', which some speakers pronounced [вевn]]), were omitted, in addition to words with creaky voice or whispered phonation.

Table 4. Words for acoustic analysis

\begin{tabular}{|c|c|c|}
\hline Stressed vowel & Disyllables & Trisyllables \\
\hline $\begin{array}{l}\text { Long (preceding lenis } \\
\text { consonant) }\end{array}$ & $\begin{array}{l}\text { babig /'ba:bik/ 'baby' } \\
\text { buzhug /'by:zyk/ 'earthworms' } \\
\text { dañvad /'dã:vat/ 'sheep' } \\
\text { labous /'la:bus/ 'bird' } \\
\text { perenn /'pe:ren/ 'pear' }\end{array}$ & $\begin{array}{l}\text { bananez /bã'nã:nes/ 'bananas' } \\
\text { daoulagad /dow'la:gat/ 'eyes' } \\
\text { kevnidenn /kẽw' ni:den/ 'spider' } \\
\text { kurunenn /ky'rỹ:nen/ 'crown' } \\
\text { logodenn /lo'go:den/ 'mouse' }\end{array}$ \\
\hline $\begin{array}{l}\text { Short (preceding } \\
\text { fortis consonant or } \\
\text { cluster) }\end{array}$ & $\begin{array}{l}\text { fourmaj /'furmaJ/ 'cheese' } \\
\text { kastell /'kastcl/ 'castle' } \\
\text { kistin /'kistĩn/ 'chestnuts' } \\
\text { touseg /'tus:ek/ 'toad' }\end{array}$ & $\begin{array}{l}\text { balafenn /ba'laf:cn/ 'butterfly' } \\
\text { bolotenn /bo'lot:cn/ 'ball' } \\
\text { fourchetez /fur' Jet:cs/ 'forks' } \\
\text { karotez /ka'rot:cs/ 'carrots' } \\
\text { legumaj /le'gym:aJ/ 'vegetables' } \\
\text { tomatez /to' mat:cs/ 'tomatoes' }\end{array}$ \\
\hline
\end{tabular}

To determine whether the contrast in length between fortis and lenis consonants, and the resulting contrast between long and short vowels is being maintained by speakers from the two different age groups, a mixed effects linear regression model was run separately on the duration of stressed vowels and of the following consonant. For the stressed vowels, the factors were Group (older speakers or younger speakers), Vowel Height (high, mid or low), Vowel Length (short or long), and Syllables (disyllabic or trisyllabic) with Speaker as a random factor nested under Group. For the following consonants, the factors were Group (older speakers or younger speakers), Segment Length (lenis or fortis), and Syllables (disyllabic or trisyllabic), again with Speaker as a random factor nested under Group. 
For the vowels, there was a significant effect of Vowel Length ( $d f=1$, F Ratio $=138.34, p<$ 0.0001 ) and of Vowel Length $\times$ Syllables ( $d f=1, F$ ratio $=4.32, p=0.039$ ), indicating that long vowels do indeed have a longer duration than short vowels, and this is true of both speaker groups (see Table 6 for details of the significant effects). In disyllables, short vowels are shorter and long vowels are longer; however, posthoc t-tests reveal that there is no statistically significant difference between the long vowels or short vowels in each type of noun. The mean values are given in Table 5.

Table 5. Mean duration of stressed vowels (ms)

\begin{tabular}{lll}
\hline & Short vowels & Long vowels \\
\hline Disyllables & 83.3 & 153.1 \\
Trisyllables & 91.5 & 140.1 \\
\hline Average & 87.4 & 146.8 \\
\hline
\end{tabular}

Table 6. Duration of stressed vowels: significant main effects ${ }^{6}$

\begin{tabular}{lllllll}
\hline & $\begin{array}{l}\text { Parameter } \\
\text { estimate }\end{array}$ & $\mathbf{t}$ & DFDen & $\boldsymbol{p}$ & \multicolumn{2}{l}{$\mathbf{9 5 \% \mathbf { C l }}$} \\
\cline { 6 - 7 } & & & & & Lower & Upper \\
\hline Vowel length & -0.0029 & -11.76 & 200.3 & $<0.0001$ & -0.0339 & -0.0255 \\
$\begin{array}{l}\text { Vowel length } \mathbf{x} \\
\text { Syllables }\end{array}$ & 0.0052 & 2.08 & 194.7 & 0.039 & 0.0011 & 0.0093 \\
\hline
\end{tabular}

Looking now at the following consonant, there was a significant effect of Segment Length (df $=1, \mathrm{~F}$ Ratio $=164.53, \mathrm{p}<0.0001)$, Syllables $(\mathrm{df}=1, \mathrm{~F}$ Ratio $=31.18, \mathrm{p}<0.0001)$ and Segment Length $\times$ Syllables $(\mathrm{df}=1, \mathrm{~F}$ Ratio $=17.09, \mathrm{p}<0.0001$ ); further details are given in Table 8 . Fortis stops therefore have a significantly longer duration than lenis consonants, in both speaker groups. Additionally, a posthoc t-test reveals that fortis consonants are significantly longer in disyllabic than trisyllabic nouns ( $\mathrm{df}=1, \mathrm{~F}$ Ratio $=52.75, \mathrm{p}<0.0001$ ); however, this was not the case for lenis consonants. The mean values are given in Table 7.

Table 7. Mean duration of lenis and fortis consonants following stressed vowels (ms)

\begin{tabular}{lll}
\hline & Lenis consonants & Fortis consonants \\
\hline Disyllables & 64.2 & 134.0 \\
Trisyllables & 58.5 & 94.3 \\
\hline Average & 61.3 & 114.1 \\
\hline
\end{tabular}

\footnotetext{
${ }^{6}$ In this and further tables, DFDen = denominator degrees of freedom (the degrees of freedom for error). DFDen is calculated using the Kenward-Roger first order approximation.
} 
Table 8. Duration of consonants following a stressed vowel: significant main effects

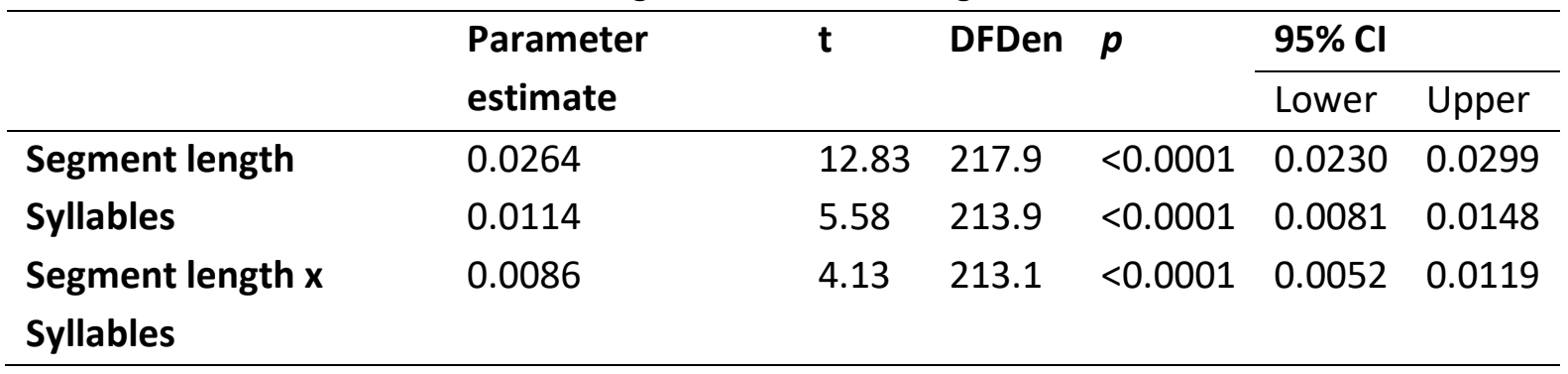

These results show, then, that older and younger speakers alike are maintaining both the contrast in length between fortis and lenis medial consonants and the resulting vowel length distinction. While older speakers' long vowels have a longer duration than those of younger speakers (mean durations $155.5 \mathrm{~ms}$ and $138.1 \mathrm{~ms}$ respectively), this difference is not statistically significant.

It is clear that there are phonemic length distinctions in Breton; the question then arises as to what the acoustic correlates of stress in Breton might be. Although measurements were made of the FO midpoint for all vowels, it was ultimately decided not to use these in this exploration of acoustic stress, for three main reasons. The first was that naturally, men's and women's voices have notably different pitches, and so the sample would have had to be split into two for the statistical analysis, halving the number of observations. The second is connected to this: many of the older speakers who took part had creaky voice, which made the FO difficult to measure, and would have resulted in a high rate of exclusions. The final issue arose from the design of the elicitation task: although speakers were asked to produce the words as naturally as possible, and they did their best to achieve this, some speakers had a tendency towards 'list intonation', with a rise in pitch towards the end of each word. It was therefore decided that it would be better not to examine F0, as these instances were likely to skew the results. This leaves duration and intensity as possible correlates of stress. Of course, in a language with a phonemic length distinction, vowel duration that is indicative of stress is less straightforward to assess, and for this reason, it was decided to measure vowel length in words with a medial fortis consonant and therefore only short vowels. The vowels in these words should (theoretically) be of a similar length, and so if duration were a (or the primary) cue to stress, it would be possible to see this.

Mixed effects linear regression models were run for duration and intensity in disyllabic and trisyllabic nouns with only short vowels (see Table 4 for details). It was necessary to analyse the two types of noun separately due to the fact that there are three vocalic positions in trisyllabic nouns, but only two in disyllabic nouns. For disyllables, the factors were Group (older or younger) Position (V1 or V2) and Vowel Height (High, Mid, Low), with Speaker as a random factor nested under Group. In trisyllables the factors were Group (older or younger) and Position (V1, V2 or V3), with Speaker as a random factor nested under Group. It was not 
possible to include Vowel Height as a factor for trisyllabic nouns, due to the distribution of the data: there were no high vowels in position V3.

Looking first at duration, in disyllables there was a significant effect of Position ( $d f=1, F$ Ratio $=4.67, p=0.0323)$, Vowel Height $(d f=2, F$ Ratio $=11.09, p<0.0001)$ and Position $x$ Vowel Height $(\mathrm{df}=2$, F Ratio $=7.28, \mathrm{p}=0.0009)$; further details are given in Table 10. Stressed vowels are indeed longer than unstressed vowels, and as we might expect, low vowels are longer than mid vowels, which are in turn longer than high vowels. Looking at the interaction between Position and Vowel Height, it is immediately clear that the difference in duration between stressed and unstressed short vowels is driven by the mid vowels, which are the only ones to differ significantly (posthoc t-test: $d f=1$, $F$ Ratio $=19.29, p<0.0001$ ).

Table 9. Mean vowel duration (ms): disyllables, short vowels only

\begin{tabular}{|c|c|c|c|}
\hline & & Po & tion \\
\hline & & V1 (stressed vowel) & V2 \\
\hline & High & 65.4 & 64.6 \\
\hline Vowel Height & Mid & 89.4 & 60.2 \\
\hline & Low & 85.0 & 90.6 \\
\hline & rage & 79.9 & 71.4 \\
\hline
\end{tabular}

Table 10. Duration of short vowels in disyllables: significant main effects (Vowel Height baseline $=$ Mid vowels)

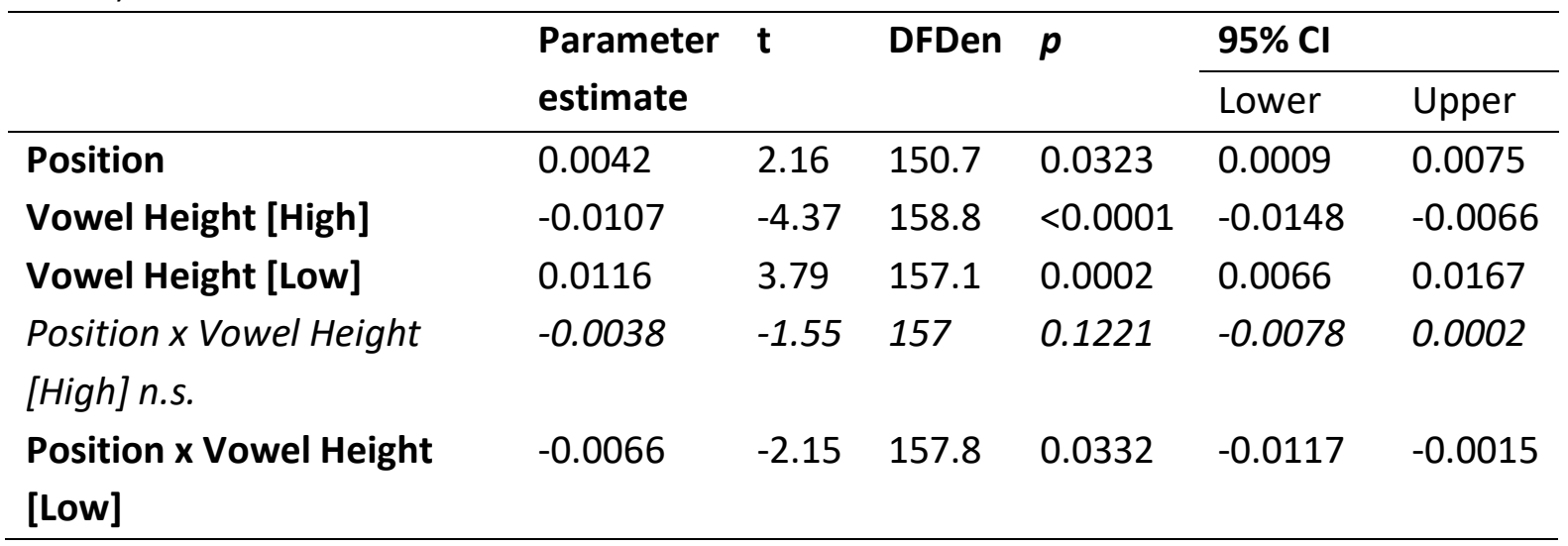

In trisyllables, there was again a significant effect of Position ( $\mathrm{df}=2, \mathrm{~F}$ Ratio $=28.11, \mathrm{p}<$ 0.0001; further details in Table 12), with the stressed vowel (V2) being significantly longer than V1 (posthoc t-test: t-ratio $=-3.77, p=0.0012$ ) and V3 (posthoc t-test: t-ratio $=-7.34, p<$ 0.0001). V3 was overall the shortest (see Table 11), which intuitively makes sense: post-tonic vowels are more likely to be reduced and in many cases (excluded from the present analysis) were deleted entirely; however, the difference between V1 and V3 was not statistically significant. 
Table 11. Mean vowel duration (ms): trisyllables, short vowels only

\begin{tabular}{llll}
\hline & \multicolumn{3}{c}{ Position } \\
\cline { 2 - 4 } & V1 & V2 (stressed vowel) & V3 \\
\hline Mean Duration & 78.8 & 90.8 & 64.8 \\
\hline
\end{tabular}

Table 12. Duration of short vowels in trisyllables: significant main effects (Position baseline $=\mathrm{V} 3$ )

\begin{tabular}{llllllll}
\hline & Parameter estimate & $\mathbf{t}$ & DFDen & $\boldsymbol{p}$ & \multicolumn{2}{l}{$\mathbf{9 5 \%} \mathbf{C l}$} & \\
\cline { 6 - 7 } & & & & & Lower & Upper \\
\hline Position [V1] n.s. & 0.0006 & 0.36 & 257.6 & 0.7209 & -0.0025 & 0.0039 \\
Position [V2] & 0.0126 & 5.86 & 258.4 & $<0.0001$ & 0.0091 & 0.0161 \\
\hline
\end{tabular}

Turning now to intensity, in disyllables there were significant effects of Position ( $d f=1, F$ Ratio 11.98, $p=0.0007$ ) and Vowel Height ( $d f=2$, F Ratio $=4.23, p=0.0164)$, but the interaction between the two was not significant (see Table 14 for further details). The stressed vowel has greater intensity than the unstressed vowel (see Table 13), and as expected, high vowels have greater intensity than mid vowels, which in turn have greater intensity than low vowels; however, only the difference between high and low vowels is statistically significant (posthoc t-test: $\mathrm{df}=1, \mathrm{~F}$ Ratio $=7.90, \mathrm{p}=0.0056)$. In trisyllables, there were significant effects of Position ( $\mathrm{df}=2$, F Ratio $=36.16, \mathrm{p}<0.0001$ ) and Group $\times$ Position ( $\mathrm{df}=2$, F Ratio $=6.0, \mathrm{p}=$ 0.0029). Looking more closely at this interaction (see details in Table 17) reveals that the younger speakers have greater intensity in both V1 and V2 than the older speakers, but that this is reversed for V3. However, for none of the individual positions is there a significant difference between the two groups, and the difference between V1 and V2 for the older speakers is not significant.

Table 13. Mean intensity mid-point (dB), disyllables

\begin{tabular}{lll}
\hline & V1 (stressed vowel) & V2 \\
\hline Intensity mid-point & 67.9 & 65.2 \\
\hline
\end{tabular}

Table 14. Intensity of short vowels in disyllables: significant main effects (Vowel Height baseline = Mid vowels)

\begin{tabular}{lllllll}
\hline & Parameter estimate & $\mathbf{t}$ & DFDen & $\boldsymbol{p}$ & & \multicolumn{2}{c}{$\mathbf{9 5 \%} \mathbf{C l}$} \\
\cline { 5 - 7 } & & & & & Lower & Upper \\
\hline Position & 1.3525 & 3.46 & 143.9 & 0.0007 & 0.7055 & 1.9995 \\
Vowel Height [High] & 1.3919 & 2.77 & 147.3 & 0.0064 & 0.5589 & 2.2250 \\
Vowel Height [Low] & -1.3697 & -2.2 & 145.9 & 0.0295 & -2.4004 & -0.3389 \\
\hline
\end{tabular}


Table 15. Mean intensity mid-point (dB), trisyllables

\begin{tabular}{lllll}
\hline & \multicolumn{3}{c}{ Position } \\
\cline { 3 - 5 } & V1 & V2 (stressed vowel) & V3 \\
\hline \multirow{2}{*}{ Group } & Older speakers & 66.1 & 67.6 & 64.2 \\
\cline { 2 - 5 } & Younger speakers & 68.3 & 68.6 & 62.7 \\
\hline \multirow{2}{*}{ Average } & 67.2 & 68.1 & 63.5 \\
\hline
\end{tabular}

Table 16. Intensity of short vowels in disyllables: significant main effects (Vowel Height baseline = Mid vowels)

\begin{tabular}{lllllll}
\hline & Parameter estimate & t & DFDen & $\boldsymbol{p}$ & & \multicolumn{2}{c}{$\mathbf{9 5 \%} \mathbf{C l}$} & \\
\cline { 5 - 7 } & & & & & Lower & Upper \\
\hline Position & 1.3525 & 3.46 & 143.9 & 0.0007 & 0.7055 & 1.9995 \\
Vowel Height [High] & 1.3919 & 2.77 & 147.3 & 0.0064 & 0.5589 & 2.2250 \\
Vowel Height [Low] & -1.3697 & -2.2 & 145.9 & 0.0295 & -2.4004 & -0.3389 \\
\hline
\end{tabular}

Table 17. Intensity of short vowels in trisyllables: significant main effects (Position baseline $=$ V3)

\begin{tabular}{|c|c|c|c|c|c|c|}
\hline & \multirow{2}{*}{$\begin{array}{l}\text { Parameter } \\
\text { estimate }\end{array}$} & \multirow[t]{2}{*}{$\mathbf{t}$} & \multirow[t]{2}{*}{ DFDen } & \multirow[t]{2}{*}{$p$} & \multicolumn{2}{|l|}{$95 \% \mathrm{Cl}$} \\
\hline & & & & & Lower & Upper \\
\hline Position [V1] & 0.9391 & 2.75 & 254 & 0.0064 & 0.3755 & 1.5027 \\
\hline Position [V2] & 1.8717 & 4.92 & 254.2 & $<0.0001$ & 1.2432 & 2.5003 \\
\hline Group x Position [V1] & -0.8390 & -2.46 & 254 & 0.0147 & -1.4026 & -0.2754 \\
\hline Group x Position [V2] n.s. & -0.2061 & -0.54 & 254.2 & 0.5888 & -0.8346 & 0.4225 \\
\hline
\end{tabular}

Overall, then, it seems that stressed short vowels may be slightly longer and have greater intensity than unstressed short vowels, but this is complicated by vowel height. It seems likely that the difference in duration observed for the disyllabic nouns is linked to the fact that unstressed vowels are often reduced, and therefore centralised, especially in this part of Brittany, and so the prevalence of reduced vowels such as schwa in final syllables may be driving this effect. It is clear that vowels in final, post-tonic syllables in both disyllabic and trisyllabic nouns are much shorter and less intense than other vowels, and this includes pretonic vowels (V1 in trisyllables). A more fine-grained acoustic study, which included F0 measures, would be needed to establish with more certainty to what degree these three measures contribute to marking stressed syllables in Breton.

One final question for acoustic analysis concerns those instances where speakers use final stress. Up until now, the analysis has only considered examples with the usual penultimate stress, but as we saw in Section 3, a small proportion of responses had final stress. Perceptually, these were largely straightforward to identify, particularly because they did not have vowel reduction in the final syllable, for example bolotenn 'ball' might be pronounced [bolot:ən] or even [bolot:n] with penultimate stress, but [bolot:عn] (or even boloten]) with final stress. The question then arises as to whether there are differences in the duration and 
intensity of the stressed and post-tonic vowels in words with final stress as opposed to words with penultimate stress; it seems likely that there are, given that there is an audible difference and the final vowel is not reduced, however, measuring this using a statistical model is problematic. As discussed above, since Breton has open syllable lengthening, duration that relates exclusively to stress can only meaningfully be measured in words with (a) fortis medial consonant(s) and therefore short vowels. Looking at the set of data for acoustic analysis (as defined above), there are just 13 disyllabic words with final stress (7\%), and 43 trisyllabic words with final stress (13\%) that could be analysed in this way.

Despite this, a tentative analysis of the data was performed in the form of an ANOVA on duration in trisyllabic nouns with short vowels only, with the factors Stress Pattern (penultimate or final) and Position (V1, V2 or V3). There were significant effects for both Position ( $\mathrm{df}=2, \mathrm{~F}$ Ratio $=5.87, \mathrm{p}=0.0031$ ) and Stress Pattern $\times$ Position ( $\mathrm{df}=2, \mathrm{~F}$ Ratio $=$ 10.33, $p<0.0001$ ). As the values in Table 18 (and, indeed, the findings that have already been discussed) indicate, while in words with penultimate stress the second vowel is significantly longer than the other vowels, with V3 being the shortest, in words with final stress no such pattern can be observed, and the vowels are not significantly different from one another.

Table 18. Vowel duration (ms) in words with penultimate and final stress (short vowels only)

\begin{tabular}{lllll}
\hline & & \multicolumn{3}{c}{ Position } \\
\cline { 3 - 5 } & & V1 & V2 & V3 \\
\hline \multirow{2}{*}{ Stress pattern } & Penultimate & 78.8 & 90.8 & 64.8 \\
\cline { 2 - 5 } & Final & 77.8 & 76.2 & 82.7 \\
\hline
\end{tabular}

This is, of course, only a preliminary, broad-brush analysis, but it gives an indication of the acoustic difference between penultimate and final stress. The next section discusses the implications of all the findings presented thus far.

\section{Discussion and analysis}

\subsection{Loanwords}

Before moving to a metrical analysis of stress in Breton, we first turn to loanwords. As mentioned in Section 2, the set of words to be elicited contained a number of loans; doing otherwise would have been very challenging, as Breton has been borrowing words from French for many centuries, and there are naturally a wide range of lexical items in Modern Breton that originated as loanwords from French. Fairly recent loans are generally easily identifiable as such, for example bananez /bã'nã:nes/ 'bananas' (< bananes) or krokodil /kro' ko: dil/ 'crocodile' (< crocodile), but older loanwords may be less transparent, particularly if the French word has subsequently changed or been lost; for example, gwastell /'gwastcl/ 'cake' < Old French gastel (cf. Modern French gâteau) or paotr /po:t(r)/ 'boy' < Old French poltre 'foal' (cf. Modern French poutre 'beam, joist'). Equally, early loanwords from Latin may 
resemble their French counterparts even though cognates exist in the other Celtic languages, for example, pont /p̃̃n(t)/ 'bridge' < Latin pons, pontem (cf. Modern French pont; Welsh pons). It can therefore be difficult to identify French loanwords, and to gauge how relevant the connections between the Breton word and its French source might be synchronically to speakers of the modern language.

Aside from the difficulties in identifying loanwords from French, the elicitation paradigm meant that speakers were free to use the word they found most natural to name the item presented in the image, and naturally, this meant that some speakers used more loanwords than others. As has already been discussed, it is claimed Neo-Breton tends to avoid French loanwords in favour of more 'Celtic' equivalents; this 'Celticisation' of Breton has its roots in the early standardisation of the language, when work by Roparz Hemon, among others, led to the creation of a 'brand new' Breton, different from the dialectal Breton of ordinary native speakers (Ó hlfearnáin, 2011). As such, the number of loanwords in the elicited data differs from speaker to speaker, and from the list of potential words to elicit.

It would have been difficult to avoid loanwords in the data, but including them provides additional data on what influences speakers' use of different stress patterns; as discussed briefly in Section 1.3.2, Jackson (1960) notes that in the Breton dialect of Plougrescant (Treger), recent loanwords from French such as bisiklet /bisi'klet/ 'bicycle' or mekanig /makã'nik/ 'machine' tend to have final stress, while earlier loanwords do not. The level of integration into the language may therefore also play a role. To investigate this further, the fieldwork responses were categorised according to their origin: ${ }^{7}$ (i) native Breton words, attested in Old Breton and/or in other Celtic languages, e.g. logodenn /lo'go:den/ 'mouse' < Celtic *lukoto, cf. Welsh Ilygod; (ii) 'old' loanwords, i.e. early loanwords from Latin into Old Breton or Brythonic, e.g. touseg /'tus:ek/ 'toad' < Latin toxicum; (iii) 'recent' loanwords, i.e. words borrowed from French at some point in the history of Breton; ${ }^{8}$ (iv) words whose etymology is unknown, such as buzhug /'by:zyk/ 'earthworms'. The data are presented in Table 19, and it does seem that loanwords are proportionately more likely to receive final stress than native words. A chi-squared test shows that the difference between the groups is significant $\left(\chi^{2}=76.49, p<0.0001\right)$, and the chi-squared standardised residuals indicate that this effect is driven by the difference between native words and 'recent' loanwords; specifically, that there is a low proportion of native words with final stress, and a high proportion of recent loanwords with final stress.

\footnotetext{
${ }^{7}$ The etymology of the Breton words is as stated in Deshayes (2003).

8 The division between 'old' and 'recent' loanwords is somewhat arbitrary; however, it divides the loanwords into those borrowed before and after Breton can reasonably be assumed to have been separate from the other Brythonic languages. There has always been a high degree of bilingualism, particularly among the upper classes, and in eastern Brittany, throughout the history of Breton, and therefore a high degree of contact with the prestige language, French.
} 
Table 19. Stress patterns in native words and loanwords; di- and trisyllables (excludes pemoc' $h$ 'pig' and amann 'butter')

\begin{tabular}{|c|c|c|c|c|}
\hline \multirow[b]{2}{*}{ Native words } & \multicolumn{2}{|c|}{ Penultimate } & \multicolumn{2}{|c|}{ Final } \\
\hline & 438 & $94.8 \%$ & 24 & $5.19 \%$ \\
\hline & \multicolumn{2}{|c|}{$\chi^{2}$ residual $=2.17$} & \multicolumn{2}{|c|}{$\chi^{2}$ residual $=-5.26$} \\
\hline \multirow[t]{2}{*}{ ‘Old’ loanwords } & 73 & $86.9 \%$ & 11 & $13.1 \%$ \\
\hline & \multicolumn{2}{|c|}{$\chi^{2}$ residual $=0.14$} & \multicolumn{2}{|c|}{$\chi^{2}$ residual $=-0.34$} \\
\hline \multirow[t]{2}{*}{ ‘Recent' loanwords } & 265 & $73.2 \%$ & 97 & $26.8 \%$ \\
\hline & \multicolumn{2}{|c|}{$\chi^{2}$ residual $=-2.53$} & \multicolumn{2}{|c|}{$\chi^{2}$ residual $=6.13$} \\
\hline \multirow[t]{2}{*}{ Unknown } & 25 & $86.2 \%$ & 4 & $13.8 \%$ \\
\hline & \multicolumn{2}{|c|}{$\chi^{2}$ residual $=0.04$} & \multicolumn{2}{|c|}{$\chi^{2}$ residual $=-0.1$} \\
\hline
\end{tabular}

It is not a surprise to find that speakers use final stress in recent loanwords from French: after all, French itself has phrase-final stress, and so the stress pattern has been borrowed along with the segmental form. This is very common cross-linguistically: Broselow (2009) notes a number of cases where the stress pattern of the donor language is preserved by the recipient language, at least to begin with, even when the borrowed stress pattern is not found in the recipient language. Dresher and Lahiri (2005) discuss the impact of French loanwords with final stress in English, and even today recent French loans in English may vary with respect to their stress pattern. What is more interesting about the Breton data is that there are crossgenerational differences with regard the type of words that receive final stress. Table 20 shows how the words receiving final stress are distributed between native words and loans, and how this differs for older and younger speakers.

Table 20. Words with final stress (excluding amann 'butter' and pemoc' $h$ 'pig')

\begin{tabular}{llllllll}
\hline & \multicolumn{2}{l}{ Native words } & \multicolumn{2}{c}{ 'Old' loanwords } & 'Recent' loanwords & Unknown \\
\hline Older speakers & 3 & $7.0 \%$ & 1 & $2.3 \%$ & 39 & $90.7 \%$ & 0 \\
Younger speakers & 21 & $22.6 \%$ & 10 & $10.8 \%$ & 58 & $62.4 \%$ & 4 \\
\hline
\end{tabular}

It is clear that older speakers' use of final stress is almost entirely confined to loanwords, while those younger speakers use final stress frequently do so in both native words and recent loans.

\subsection{Metrical analysis}

The discussion can now turn to a consideration of the metrical structure of Breton, across the two groups of speakers, in the manner of Hayes (1995). The normal penultimate stress pattern of KLT Breton that is attested in the literature can be accounted for most straightforwardly by positing syllabic (non-weight sensitive) trochees, built from right to left, with main stress on the right edge, as in (2). 


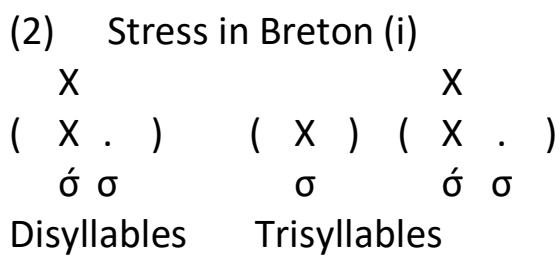

As was discussed in Section 1.3.1, syllable weight and stress interact in Breton, such that stressed syllables must be bimoraic, either containing a long vowel, or involving a fortis (i.e. long) consonant. Vowel length is not phonemic, but rather results from the nature of the following consonant, fortis or lenis, through open syllable lengthening.

Carlyle argues persuasively for final consonant extrametricality, which she uses to explain the contrast between words such as dal [da:l] and dall [dal] (see example (1) and surrounding discussion). An alternative analysis of Breton stress might therefore take this extrametricality and weight into account, and posit a quantity sensitive system that parses words into moraic trochees with main stress on the right edge, as in (3).

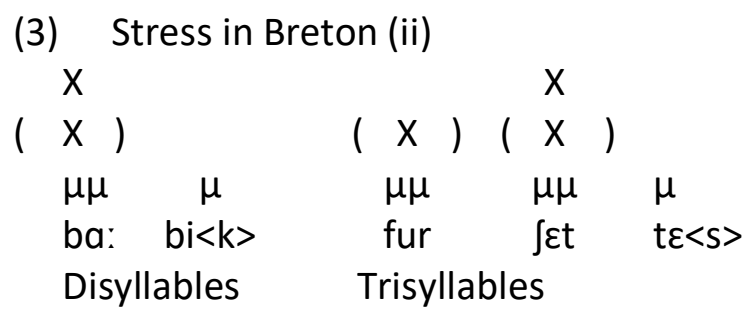

To give a concrete example, in babig 'baby' /'ba:bik/ the final consonant is extrametrical, leaving a heavy followed by a light syllable; the heavy syllable is then parsed into a single moraic trochee. The same is true in fourchetez /fur'fet:عs/ 'forks': the heavy syllables are parsed into moraic trochees and main stress is assigned at the right edge. However, this analysis is more problematic for words with medial lenis consonants, such as peskedenn 'a (single) fish' /pes'ke:den/. These forms have a long vowel in the stressed syllable, but this is the result of open syllable lengthening before the short, lenis consonant, as discussed above, and the syllable is not underlyingly heavy. This is confirmed by the morphologically related form pesked 'fish.PL' /'pesket/, from which peskedenn is derived. This is not in itself a problem for a quantity-sensitive analysis, but the analysis of these forms leads to the question of why the final syllable does not receive stress, given that it ends in a fortis nasal stop. Carlyle's analysis of $d a l$ and dall shows that only part of a fortis sonorant is extrametrical, and the evidence for a fortis stop in the singulative suffix comes from forms such as peskedennoù '(many single) fish.PL', where a plural suffix has been added to the singulative noun. The stressed vowel is short, /peske'den:u/, showing that the following consonant is fortis (this is also reflected in the $<n n>$ spelling). A quantity-sensitive analysis is only possible if the whole of a fortis sonorant is extrametrical, as in (4a), otherwise we would expect the parsing in (4b), with stress on the final syllable. 
(4) Final consonant extrametricality

(a)

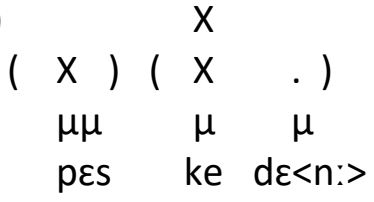

$\left({ }^{*} \mathrm{~b}\right)$

$\begin{array}{lcc} & & x \\ & x) & (x) \\ \mu \mu & \mu & \mu \mu \\ \text { pes } & \text { ke } & d \varepsilon n<n>\end{array}$

To claim that the whole of a fortis sonorant is extrametrical in this context would mean treating monosyllables differently from longer words. It therefore seems more straightforward to apply the analysis in (2), where the weight of the syllable, and consonant extrametricality, while related to stress patterns and instrumental in the analysis of segment length, do not play a role in stress assignment. Rather, syllables are parsed into syllabic trochees, and short vowels in stressed open syllables are lengthened. That speakers are abiding by these patterns is confirmed by the acoustic analysis, since speakers from both groups are maintaining the fortis/lenis distinction and the resulting open syllable lengthening.

Obviously this analysis must also be able to cope with lexical exceptions such as pemoc' ' 'pig', where the final syllable receives the main stress. Many of these exceptions occur for historical reasons, and were originally compounds, as in the case of pemoc' $h$ /pe' mo: $x$ / itself: in Breton, the right-most element of the compound receives the main stress and pemoc' $h$ is thought to derive from earlier penn-moc'h (cf. penn-deñved and penn-ognon, above). The earlier structure of these words is reflected in the stress pattern, and they must therefore be marked in the lexicon as having final stress.

(5) Stress pattern in pemoc' $h$ 'pig' $x$

(X) (X)

$\left[\begin{array}{ll}\sigma & {[\sigma}\end{array}\right]$

pe. mó:x

Other exceptions include derived words such as lakaat /la'ka:t/ 'to put' or pesketaer /peske'tacr/ 'fisherman', where the penultimate and final syllables are contracted into a single syllable, but the stress is preserved in situ. This satisfies the need for a stressed syllable to be bimoraic without lengthening the vowel in the penultimate syllable. Most languages have at least some words that fail to conform to the predominant stress pattern (van der Hulst, 1999), and often these are loanwords (Peperkamp, 2004); recent work on the typology of stress patterns (van der Hulst, 2014) has found that in a sample of 511 languages, 70 had significant numbers of exceptions. Since the number of words with final stress in KLT Breton is relatively small, it seems sensible to regard them as a separate subsystem. 
The fieldwork data from this study indicate that in disyllables, the expected KLT pattern is maintained: speakers stress the penultimate syllable. Older speakers also maintain this pattern in trisyllabic nouns, the only exceptions being certain loanwords from French, which, as has already been discussed, may retain their original final-stress pattern, and thus must also be lexically marked. Indeed, many of these loanwords show interspeaker variation in their stress pattern, suggesting that they are in the process of being adapted to Breton penultimate stress (e.g. harikoù /ha'rik:u/ 'French beans').

Younger speakers, on the other hand, show more variability in trisyllables. Four of the younger speakers (HY, MZ, TG and YP) use predominantly penultimate stress, like the older speakers, and it can therefore be assumed that these speakers share the metrical structure outlined above. Two speakers (FO and XX) use predominantly final stress in trisyllables, while the remaining three speakers (ND, IQ and $A J$ ) fall somewhere between these two extremes. Two questions arise: first, why are trisyllables being treated differently from disyllables? Secondly, what, if anything, conditions the use of the two stress patterns for those speakers where there is variation?

It seems likely that some younger speakers of Breton are struggling with two competing stress systems: the Breton penultimate system, with syllabic trochees and main stress right, and their native French stress system. In contrast to some other languages (e.g. Latin), stress in French has proved more difficult to describe from a metrical standpoint, and is still the subject of disagreement in the literature. Stress is not contrastive in French, and primary stress falls on the final full syllable; that is, the final syllable that is not schwa (e.g. garçón 'boy'; possible 'possible') (Di Cristo, 1998). In addition, the unit to receive this primary stress is the phonological phrase (Dell, 1984), rather than the prosodic word, as we have come to expect from many languages (Hayes, 1995). The stress-bearing phrase has been further described as the 'tonal unit' (Di Cristo, 2011) and the 'Accentual Phrase' (Sichel-Bazin et al., 2015).

There has been much discussion about French metrical structure, and whether or not it can be said to have metrical feet (see, e.g. Scullen, 1997; Goad \& Buckley, 2006; Andreassen \& Eychenne, 2013; Sichel-Bazin et al., 2015), but however we choose to analyse stress in French, it seems clear that it is markedly different from stress in Breton. Even if French does have trochees, a fact that is in some doubt, they cannot account for the system of stress as a whole, and thus belong only to a small part of the overall prosodic system. New speakers of Breton must therefore cope with two distinct systems, and it would seem that interference from French is affecting some speakers' use of stress in Breton. The first question to be addressed is why all speakers seem to have acquired the penultimate stress pattern in disyllables, but not in trisyllables. It seems possible that this is due to a different metrical analysis. Recall that under the current analysis, stress in Breton relies on syllabic trochees built from right to left, with the main stress on the right; this results in penultimate stress. It is clear from disyllabic 
nouns that all speakers are able to parse syllables into trochees - there is no reason to assume, for example, that the final syllable is extrametrical and the first syllable forms an iamb. In a disyllabic noun, however, the direction of parsing and the main stress rule are somewhat irrelevant: it does not matter at which edge the speaker starts to build feet, and there is only one syllable available to receive main stress. In trisyllabic nouns, however, speakers have a greater degree of choice: building feet from the right edge will result in a stressed penult, while starting at the left edge will give stresses on the initial and final syllables. The most straightforward analysis, then, would see the younger Breton speakers parsing from the left edge, and placing main stress on the right-most syllable: the final one.

(6) Contrasting stress patterns in trisyllables

\begin{tabular}{|c|c|}
\hline Traditional Breton: $\mathrm{R} \rightarrow \mathrm{L}$ & New Breton: $L \rightarrow R$ \\
\hline $\mathrm{x}$ & $\mathrm{x}$ \\
\hline$(x) \quad(x)$. & $(x)$. \\
\hline$\sigma \sigma$ & $\sigma \sigma$ \\
\hline
\end{tabular}

This analysis, building on that in (2), is supported by the (limited) evidence from the acoustic analysis: in words with penultimate stress, younger speakers are maintaining the segment length distinctions discussed in Section 3.1.3, and the analysis in (6) does not require an explanation of why younger speakers are not maintaining final consonant extrametricality, as an account built on the analysis in (3) would need to do. In contrast, younger speakers may not be reducing unstressed vowels, and where they do use final stress, they may not lengthen the vowel in a penultimate syllable followed by a lenis consonant, since there is no motivation to do so. This may be more instrumental in the variation in stress patterns observed in Section 3 , and will be discussed further below.

How does this analysis fit in with influence from French? It is difficult to say for certain, but parsing from left to right produces a structure in longer words that is much more similar to that of French, namely the main stress on the final syllable and a possible secondary stress on the initial syllable. The issue of secondary stress has not yet been addressed; however, a number of writers have observed secondary stress in longer Breton words. Sommerfelt (1921) writes that in the Breton of Saint-Pol-de-Leon, words of four or five syllables have penultimate main stress, and a secondary stress on the first or second syllable of the word respectively. Jackson (1967) adds that in Tregerieg words of four or five syllables may have secondary stress on the first or second syllable, but notes that this is not consistently reported. He further writes that in Gwenedeg, where stress is normally on the final syllable, there is a tendency for there to be secondary stress on the antepenult, and while reduction of unstressed syllables indicates that this secondary stress once had marked intensity, in contemporary Breton, it is very much like French. Longer words were not part of the fieldwork task in this study; however, given the nature of the task, which allowed speakers to choose the response themselves, one or two instances of words with more than three syllables were recorded, such as fourchetezenn /, furfe'te:zen/ 'fork'. With only a handful of examples, it is difficult to 
say whether or not speakers are using secondary stress as expected, however, it does seem that some of these instances may have a secondary stress where the analysis would predict. Further research would be needed to explore this.

These observations suggest that the metrical analysis proposed in (5) above is an accurate representation of Breton stress, since it predicts secondary stresses in longer words. For speakers who use the 'new' metrical pattern, the analysis predicts secondary stress on the antepenultimate syllables, which gives a surface realisation not dissimilar to that of French, as discussed above. Therefore, although the underlying structure is different from that of French, the surface realisation is the same, and this phenomenon is therefore similar in nature to pertinacity, as discussed by Dresher \& Lahiri (2005: 75): 'a rule or pattern may persist over time, though its realization may change'. Here, the surface pattern has been carried over from French, but has been partially accommodated to Breton metrical structure.

The final question concerns the variability in the 'middle' younger speakers - that is, the speakers who use both penultimate and final stress in trisyllables (34-64\% final stress). Table 21 shows the distribution of penultimate and final stress across lexical items for these four speakers. 
Table 21. Distribution of stress patterns across lexical items (speakers XX, ND, IQ and AJ); shaded cells indicate lenis consonants/long stressed vowels; unshaded cells indicate fortis consonants/short stressed vowels

\begin{tabular}{|c|c|c|}
\hline Always penultimate stress & Always final stress ${ }^{9}$ & Mixture of stress patterns \\
\hline amanenn 'piece of butter' & biskoulenn 'caterpillar' & balafenn 'butterfly' \\
\hline /ã'mã:nen/ & /bis'ku:len/, /bisku'len/ & /ba'laf:cn/, /bala'f:cn/ \\
\hline bananez 'bananas' & bolotenn 'ball' & chokolad 'chocolate' \\
\hline /bã'nã:nعs/ & /bo'lot:cn/, /bolo't:cn/ & /Jo'ko:lat/, /Joko'lat/ \\
\hline boujienn 'candle' & gwennili 'swallows' & legumaj 'vegetables' \\
\hline /bu'zi:cn/ & /guع'ni:li/, /gyeni'li/ & /le'gỹm:as/, /legỹ'm:aJ/ \\
\hline bugale 'children' & horolaj 'clock' & logodenn 'mouse' \\
\hline /by'ga:le/ & /o'ro:las/, /oro'laj/ & /lo'go:den/, /logo'den/ \\
\hline daoulagad 'eyes' & kistinoù 'chestnuts' & Iunedoù 'spectacles' \\
\hline /dow'la:gat/ & /kis'tĩ:nu/, /kistĩ'nu/ & /Iỹ'ne:du/, /lỹne'du/ \\
\hline fourchetez 'forks' & krokodil 'crocodile' & saladenn 'salad' \\
\hline /fur' Jet:cs/ & /kro'ko:dil/, /kroko'dil/ & /sa'la:den/, /sala'den/ \\
\hline frambouezenn 'raspberry' & Iuduenn 'cinder' & steredenn 'star' \\
\hline /frãm'bwe:zen/ & /ly'dy:cn/, /lydy'en/ & /ste're:den/, /stere'den/ \\
\hline gwenanenn 'bee' & olifant 'elephant' & tomatez 'tomatoes' \\
\hline /guẽ'nãnen/ & /o'lif:ãnt/, /oli'f:ãnt/ & /to'mat:عs/, /toma't:عs/ \\
\hline gwespedenn 'wasp' & pompinell 'doll' & \\
\hline /gues'pe:den/ & /pכ̃m'pĩ:nعl/, /pכ̃mpĩ'nعl/ & \\
\hline \multicolumn{3}{|l|}{ karotez 'carrots' } \\
\hline \multicolumn{3}{|l|}{ /ka'rot:عs/ } \\
\hline \multicolumn{3}{|l|}{ kevnidenn 'spider' } \\
\hline \multicolumn{3}{|l|}{ /kẽw'ni:den/ } \\
\hline \multicolumn{3}{|l|}{ kurunenn 'crown' } \\
\hline \multicolumn{3}{|l|}{ /ky'ry:nen/ } \\
\hline \multicolumn{3}{|l|}{ labousig 'little bird' } \\
\hline \multicolumn{3}{|l|}{ /la'bus:ik/ } \\
\hline \multicolumn{3}{|l|}{ orañjez 'oranges' } \\
\hline \multicolumn{3}{|l|}{ /J'rãzદs/ } \\
\hline \multicolumn{3}{|l|}{ pinochez 'spinach' } \\
\hline \multicolumn{3}{|l|}{ /pĩ'nof:عs/ } \\
\hline sivienn 'strawberry' & & \\
\hline /si'vi:cn/ & & \\
\hline
\end{tabular}

It can be observed, first of all, that speakers do not agree on the same stress pattern for the same lexical items: eight items have a mixture of stress patterns across the four speakers. As

\footnotetext{
${ }^{9}$ Where two IPA transcriptions are given in Table 21, the first is the Standard Breton pronunciation (with penultimate stress) and the second is an approximation of speakers' pronunciation with final stress, and consequently no segment lengthening.
} 
discussed in the previous section, recent loans tend to receive final stress, and yet that does not appear to explain what is happening here: while krokodil 'crocodile' and olifant 'elephant' receive final stress from all speakers, there are a number of loanwords which receive penultimate stress from all speakers, such as karotez 'carrots' and bananez 'bananas'. However, while these words might appear to differ in stress pattern from their French source, in fact the structure of the Breton words is different, as they include the suffix -ez, a common means of borrowing a noun as plural. The French schwa in carottes 'carrots' or bananes 'bananas' is not stressed, and may not even be pronounced, with the result that the Breton words in fact preserve the stress pattern found in the French source: carottes /kaRot/ with phrase-final stress > karótez /ka'rot:عs/. The same pattern can be observed with the singulative suffix -enn in saládenn < salade and framboézenn < framboise.

Of course, not all the words in Table 21 are recent loanwords; there are still some unaccounted for. Table 22 shows the remaining words.

Table 22. Distribution of stress patterns across lexical items; recent loanwords excluded (speakers XX, ND, IQ and AJ); shaded cells indicate long stressed vowels; unshaded cells indicate short stressed vowels

\begin{tabular}{|c|c|c|}
\hline Always penultimate stress & Always final stress & Mixture of stress patterns \\
\hline amannenn 'piece of butter' & biskoulenn 'caterpillar' & balafenn 'butterfly' \\
\hline /ã'mã:nen/ & /bis'ku:len/, /bisku'len/ & /ba'laf:en/, /bala'f:cn/ \\
\hline bugale 'children' & bolotenn 'ball' & logodenn 'mouse' \\
\hline /by'ga:le/ & /bo'lot:cn/, /bolo't:cn/ & /lo'go:den/, /logo'den/ \\
\hline daoulagad 'eyes' & gwennili 'swallows' & steredenn 'star' \\
\hline /dow'la:gat/ & /gyz'ni:li/, /gyeni'li/ & /ste're:den/, /stere'den/ \\
\hline gwenanenn 'bee' & kistinoù 'chestnuts' & \\
\hline /gyẽ'nãnen/ & /kis'tĩ:nu/, /kistî'nu/ & \\
\hline gwespedenn 'wasp' & luduenn 'cinder' & \\
\hline /gyes'pe:den/ & /ly'dy:cn/, /lydy'en/ & \\
\hline kevnidenn 'spider' & pompinell 'doll' & \\
\hline /kẽw'ni:den/ & /pכ̃m'pĩ:nعl/, /pכ̃mpĩ'nعl/ & \\
\hline \multicolumn{3}{|l|}{ kurunenn 'crown' } \\
\hline \multicolumn{3}{|l|}{ /ky'ry:nen/ } \\
\hline \multicolumn{3}{|l|}{ labousig 'little bird' } \\
\hline \multicolumn{3}{|l|}{ /la'bus:ik/ } \\
\hline \multicolumn{3}{|l|}{ sivienn 'strawberry' } \\
\hline /si'vi:cn/ & & \\
\hline
\end{tabular}

If the analysis presented above is correct, the question we face is what drives a speaker to select either of the two directions when parsing a word into feet. The very fact that the speakers do not 'agree' on the stress patterns for certain words suggests that there is no cutand-dried answer. The distribution of fortis and lenis medial consonants, and the resulting 
short and long vowels, also does not seem to play a role; it is not the case, for example, that words with a medial lenis stop, and the potential for a long vowel, are more likely to have penultimate stress. However, certain tendencies can nonetheless be observed. Speakers are more likely to use penultimate stress if the penult is a low vowel (e.g. bugale 'children'); indeed, as the measurements in Section 4 showed, low vowels tend to be longer in any case. Final stress is more likely when the penult has a high vowel. There are of course several exceptions to this: balafenn 'butterfly' is found with both stress patterns, despite having a low vowel in the penult, and both kevnidenn 'spider' and kurunenn 'crown' have penultimate stress, despite having high vowels in the penult. As mentioned above, acoustic measurements seem to suggest than in trisyllabic words with final stress, speakers are not reducing the unstressed vowels. It may be that a lack of vowel reduction, perhaps driven by spelling pronunciation linked to high levels of literacy among younger, but not older, speakers, is adding to younger speakers' confusion over stress patterns. If the final vowel is not reduced, it may be more easily interpreted as stressed, and therefore reproduced as such.

In summary, speakers from both generations are more likely to use word-final stress in loanwords from French, preserving the stress pattern of the donor language. These words may eventually be adapted to Breton penultimate stress patterns. All younger speakers use penultimate stress in disyllables, but some younger speakers also use final stress in certain trisyllables. It is likely that this arises due to competing metrical structures: the 'normal' penultimate stress pattern parses syllables into trochees from right to left, while final stress is obtained by parsing from left to right. This latter pattern may arise as a result of influence from French, where the primary stress falls on the final syllable in a phonological phrase. It is unclear what motivates speakers to choose one or the other of these two patterns for individual lexemes; it may be due to phonological factors, such as the vowel in the penultimate syllable, but equally it may be due to other factors such as frequency, which cannot be investigated here.

\section{Conclusions}

Although long-term, intense language contact can lead to changes in the prosody of a language, this study shows that this is not necessarily the case, and that native prosodic systems can be surprisingly resistant to outside influence. Given the sociolinguistic context in which Breton is spoken, that is, as a minority language with an ever-diminishing pool of elderly native speakers, and a French-dominant younger generation whose linguistic input in Breton may be severely restricted, we might expect that the language would be subject to radical restructuring, with changes at all levels of linguistic organisation. Indeed, it has been claimed that language attrition is affecting the Breton of older speakers (Dressler, 1991), and that younger speakers use an artificial-sounding 'Neo-Breton', which prefers Celtic neologisms but shows influence from French in its morphosyntax and phonology (Jones, 1995). However, with regard to lexical stress, this does not seem to be the case; at least, not for all speakers 
and in all contexts. Traditional speakers of Kerneveg Breton use stress almost exactly as expected: namely, with the main stress on the penultimate syllable of the word, apart from a small number of recognised exceptions, which have final stress. To these exceptions, we might add a number of very recent loanwords from French, where the similarity between the French and Breton words is very much apparent; however, this varies from speaker to speaker depending on the degree of integration into the individual speaker's phonological system.

Younger 'new' speakers of Breton largely use stress in the same way as the older traditional speakers in this area, in contrast to claims that have been made in the literature (e.g. Madeg, 2010). Rather, disyllabic and trisyllabic words show an asymmetry, since the latter are much more likely to receive final stress. Acoustic measurements show that the quantity contrast in both vowels and consonants is being maintained by speakers of all ages, and that while stress appears to be expressed through increased duration and intensity, this interacts with vowel height, and therefore the reduction of unstressed vowels is likely to play a more important role in speakers' production of stress.

However, this pattern of stress usage is not true of all speakers, which indicates that new Breton speakers are far from being a homogeneous group. It seems that some speakers may be influenced by French in their use of stress patterns. While traditional speakers and some younger speakers parse words into trochees from right to left, a competing pattern, parsing from left to right, seems to be used by other younger speakers. Speakers may additionally be influenced by the phonological shape of the word, whereby low vowels are more likely to receive final stress. Equally, speakers may preserve the stress pattern of French loanwords, which may in turn lead either to final stress, as in ananás 'pineapple' (< French ananás) or to penultimate stress, as in karótez 'carrots' (< French caróttes), thus actually maintaining the wider Breton pattern. It is also possible that a lack of unstressed vowel reduction among younger speakers is leading to confusion about which syllable in a word is stressed, but more investigation is needed to establish if this is the case. The influence of French on Breton prosody is therefore far more complex than we might be led to believe, and is resulting in increased variation in stress across speakers of differing linguistic background, as well as patterns of both change and maintenance. 
Appendix A: Breton orthography

Pronunciation relates to Standard Breton; dialects may vary.

\begin{tabular}{|c|c|}
\hline Grapheme & IPA \\
\hline $\mathrm{b}$ & $b$ \\
\hline ch & $\int$ \\
\hline$c^{\prime} h$ & hor $x$ \\
\hline d & d \\
\hline$f$ & $f$ \\
\hline g & $\mathrm{g}$ \\
\hline $\mathrm{h}$ & h, or silent \\
\hline j & 3 \\
\hline k & $\mathrm{k}$ \\
\hline I & I \\
\hline $\mathrm{m}$ & $\mathrm{m}$ \\
\hline $\mathrm{n}$ & $\mathrm{n}$ \\
\hline$p$ & $p$ \\
\hline$r$ & $\mathrm{~b}, \mathrm{R}$ or $\mathrm{r}$ \\
\hline s & $\mathrm{s}$ \\
\hline $\mathrm{t}$ & $\mathrm{t}$ \\
\hline$v$ & v \\
\hline w & w or v \\
\hline$z$ & z \\
\hline $\mathrm{zh}$ & $z$ or h \\
\hline gn & $\mathrm{n}$ \\
\hline lh & $\Lambda$ \\
\hline $\mathrm{a}$ & $\mathrm{a}$ \\
\hline e & e or $\varepsilon$ \\
\hline i & i \\
\hline 0 & o or o \\
\hline $\mathrm{u}$ & $\mathrm{y}$ \\
\hline ao & כ \\
\hline eu & $\varnothing$ or \\
\hline ou & $\mathrm{u}$ \\
\hline
\end{tabular}

Note:

Vowels are nasalised before nasal consonants; $<\tilde{n}>$ marks a preceding vowel as nasal, but is not pronounced.

Word-final obstruents are voiced before a following sonorant, but voiceless elsewhere. 


\section{References}

Adkins, Madeleine. 2013. 'Will the real Breton please stand up? Language revitalization and the problem of authentic language' International Journal of the Sociology of Language 223: $55-70$

Anderson, Stephen R. 1981. 'Why Phonology Isn't "Natural"' Linguistic Inquiry 12(4): 493-539

Andreassen, Helene N. \& Julien Eychenne. 2013. 'The French foot revisited' Language Sciences 39: $126-140$

Avezard, Cécile. 1999. 'La dynamique linguistique du breton' in Pierre Parlebas (ed.) Le corps et le langage: parcours accidentés (Paris: L'Harmattan) 73-92

Balcou, Jean \& Yves Le Gallo. (eds.) 1997. Histoire littéraire et culturelle de la Bretagne (Paris - Spezed: Champion - Coop Breizh)

Ball, Martin J. \& Nicole Müller. 1992. Mutation in Welsh (London: Routledge)

Boersma, Paul \& David Weenink. 2018. Praat: doing phonetics by computer. [Computer Program]. Version 6.0.21, retrieved from http://www.praat.org/

Broselow, Ellen. 2009. 'Stress adaptation in loanword phonology: perception and learnability' in Paul Boersma \& Silke Hamann (eds.) Phonology in Perception (Berlin: Mouton) 191-234

Broudic, Fañch. 2009. Parler breton au XXIe siècle: Le nouveau sondage de TMO-Régions (Brest: Emgleo Breiz)

Campbell, Lyle \& Martha C. Muntzel. 1989. 'The structural consequences of language death' in Nancy C. Dorian (ed.) Investigating obsolescence: studies in language death (Cambridge: Cambridge University Press)

Carlyle, Karen. 1988. 'A syllabic phonology of Breton' (PhD, University of Toronto)

Costa, James. 2015. 'New speakers, new language: on being a legitimate speaker of a minority language in Provence' International Journal of the Sociology of Language 2015(231): 127-145

Davies-Deacon, Merryn. 2017. 'The online presence of standard and non-standard Breton' Paper presented at Annual Conference of the Society for French Studies, University of Durham, 3rd-5th July 2017.

de Lacy, Paul. 2014. 'Evaluating evidence for stress systems' in Harry van der Hulst (ed.) Word Stress: Theoretical and Typological Issues (Cambridge: Cambridge University Press) 149-193

Dell, François. 1984. 'L'accentuation dans les phrases en français' in François Dell, Daniel Hirst \& Jean-Roger Vergnaud (eds.) Forme sonore du langage : structure des répresentations en phonologie (Paris: Hermann) 65-122 
Desbordes, Yann. 1983. Petite grammaire du breton moderne (Lesneven: Mouladurioù Hor Yezh)

Deshayes, Albert. 2003. Dictionnaire étymologique du breton (Douarnenez: Le Chasse-Marée)

Di Cristo, Albert. 1998. 'Intonation in French' in Daniel Hirst \& Albert Di Cristo (eds.) Intonation Systems: a survey of twenty languages (Cambridge: Cambridge University Press) 195-218

Di Cristo, Albert. 2011. 'Une approche intégrative des relations de l'accentuation au phrasé prosodique du français' French Language Studies 21: 73-95

Dogil, Grzegorz \& Briony Williams. 1999. 'The phonetic manifestation of word stress' in Harry van der Hulst (ed.) Word prosodic systems in the languages of Europe (Berlin; New York: Mouton de Gruyter) 273-334

Dresher, Elan \& Aditi Lahiri. 2005. 'Main stress left in Early Middle English' in Michael Fortescue, Eva Skafte Jensen, Jens Erik Mogensen \& Lene Schøsler (eds.) Historical Linguistics 2003: Selected papers from the 16th International Conference on Historical Linguistics, Copenhagen, 11-15 August 2003 (Amsterdam: John Benjamins Publishing Company) 75-85

Dressler, Wolfgang U. 1972. 'On the Phonology of Language Death' Proceedings of the Chicago Linguistics Society 8: 448-457

Dressler, Wolfgang U. 1991. 'The sociolinguistic and patholinguistic attrition of Breton phonology, morphology and morphonology' in Herbert W. Seliger \& Robert Michael Vago (eds.) First Language Attrition (Cambridge: Cambridge University Press) 99-112

Dupoux, Emmanuel, Christophe Pallier, Nuria Sebastian \& Jacques Mehler. 1997. 'A Destressing "Deafness" in French?' Journal of Memory and Language 36: 406-421

Dupoux, Emmanuel, Sharon Peperkamp \& Núria Sebastián-Gálles. 2001. 'A robust method to study stress "deafness"' Journal of the Acoustical Society of America 110(3): 1606-1618

Falc'hun, François. 1947. 'L'accentuation du Breton' Annales de Bretagne 54(1): 1-11

Falc'hun, François. 1951. Le système consonantique du breton; avec une étude comparative de phonétique expérimentale (Rennes: Plihon)

Frost, Dan. 2011. 'Stress and cues to relative prominence in English and French: a perceptual study' Journal of the International Phonetic Association 41: 64-84

Goad, Heather \& Meaghen Buckley. 2006. 'Prosodic Structure in Child French: Evidence for the Foot' Catalan Journal of Linguistics 5: 109-142 
Gordon, Matthew. 2011. 'Stress: phonotactic and phonetic evidence' in Marc van Oostendorp, Colin J. Ewen, Elizabeth Hume \& Keren Rice (eds.) The Blackwell Companion to Phonology (Malden, Mass.: Wiley-Blackwell) II: 924-948

Hamp, Eric P. 1951. 'Morphophonemes of the Keltic Mutations' Language 27(3): 230-247

Hayes, Bruce. 1995. Metrical Stress Theory: Principles and Case Studies (Chicago: University of Chicago Press)

Hemon, Roparz. 1941. Grammaire bretonne (Brest: Al Liamm)

Hewitt, Steve. 1977. 'The Degree of Acceptability of Modern Literary Breton to Native Breton Speakers' (Diploma of Linguistics Thesis, University of Cambridge)

Himmelmann, Nikolaus P. \& D. Robert Ladd. 2008. 'Prosodic Description: An Introduction for Fieldworkers' Language Documentation and Conservation 2(2): 244-274

Hornsby, Michael. 2005. 'Néo breton and questions of authenticity' Estudios de Sociolingüística 6(2): 191-218

Hornsby, Michael. 2014. "Une prononciation déficiente, francisée': The debate over an "authentic" accent in revitalized Breton' Zeszyty Łużyckie 48: 149-171

Hornsby, Michael. 2015. Revitalizing Minority Languages: New Speakers of Breton, Yiddish and Lemko (Basingstoke: Palgrave Macmillan)

Hulst, Harry van der. (ed.) 1999. Word prosodic systems in the languages of Europe (Berlin; New York: Mouton de Gruyter)

Hulst, Harry van der. 2014. 'The study of word accent and stress: past, present, and future' in Harry van der Hulst (ed.) Word stress: theoretical and typological issues (Cambridge: Cambridge University Press) 3-55

Humphreys, Humphrey Lloyd. 1995. Phonologie et morphosyntaxe du parler breton de Bothoa en Saint-Nicolas-du-Pélem (Côtes-d'Armor) (Brest: Ar Skol Vrezoneg; Emgleo Breiz)

Jackson, Kenneth Hurlstone. 1960. 'The phonology of the Breton dialect of Plougrescant' Études Celtiques 9: 327-404

Jackson, Kenneth Hurlstone. 1967. A historical phonology of Breton (Dublin: Dublin Institute for Advanced Studies)

Jaeger, Jeri J. 1983. 'The fortis/lenis question: evidence from Zapotec and Jawoñ' Journal of Phonetics 11: 177-189

Jaffe, Alexandra. 2015. 'Defining the new speaker: theoretical perspectives and learner trajectories' International Journal of the Sociology of Language 2015(231): 21-44 
Jones, Mari C. 1995. 'At What Price Language Maintenance? Standardization in Modern Breton' French Studies: A Quarterly Review 49(4): 424-438

Jones, Mari C. 1998. Language Obsolescence and Revitalization: Linguistic Change in Two Sociolinguistically Contrasting Welsh Communities (Oxford: Clarendon Press)

Jouitteau, Mélanie. 2018. 'Children prefer natives: a study on the transmission of a heritage langugage - Standard Breton, neo-Breton and traditional dialects' in Maria Bloch-Trojnar \& Mark Ó Fionnáin (eds.) Centres and peripheries in Celtic linguistics (Berlin: Peter Lang) 75-108

Jun, Sun-Ah \& Cécile Fougeron. 2000. 'A phonological model of French intonation' in Antonis Botinis (ed.) Intonation: analysis, modelling and technology (Dordrecht: Kluwer) 209-242

Kasstan, Jonathan. 2017. 'New speakers: challenges and opportunities for variationist sociolinguistics' Language and Linguistics Compass 11: 1-16

Kennard, Holly J. 2014. 'The persistence of verb second in negative utterances in Breton' Journal of Historical Linguistics 4(1): 1-39

Kennard, Holly J. \& Aditi Lahiri. 2017. 'Mutation in Breton verbs: Pertinacity across generations' Journal of Linguistics 53(1): 113-145

Le Grézause, Esther. 2018. Praatscript: 'Get duration, pitch, intensity, formants'. [Computer Program]. retrieved from https://depts.washington.edu/phonlab/resources/fO-F1-F2intensity_praat_script.praat

Le Pipec, Erwan. 2013. 'Les trois ruptures sociolinguistiques du breton' International Journal of the Sociology of Language 2013(223): 103-116

Lüpke, Frederike. 2009. 'Data collection methods for field-based language documentation' in Peter K. Austin (ed.) Language Documentation and Description (London: SOAS) 6: 53-100

Madeg, Mikael. 2010. Traité de prononciation du Breton du Nord Ouest (Brest: Emgleo Breizh)

Matras, Yaron. 2009. Language contact (Cambridge: Cambridge University Press)

McDonald, Maryon. 1989. 'We are not French!' Language, culture and identity in Brittany (London; New York: Routledge)

McEwan-Fujita, Emily. 2010. 'Ideology, affect and socialization in language shift and revitalization: The experience of adults learning Gaelic in the Western Isles of Scotland' Language in Society 39: 27-64

McKenna, Malachy. 1988. A Handbook of Modern Spoken Breton (Tübingen: Niemeyer) 
McLeod, Wilson \& Bernadette O'Rourke. 2015. '"New speakers" of Gaelic: Perceptions of linguistic authenticity and appropriateness' Applied Linguistics Review 6(2): 151-172

Milroy, Lesley. 1980. Language and Social Networks (Oxford: Blackwell)

Moal, Stefan. 2003. 'How can one be a Breton speaker in the twenty-first century?' Contemporary French Civilization 27(2): 329-355

Nance, Claire. 2015. "New' Scottish Gaelic speakers in Glasgow: A phonetic study of language revitalisation' Language in Society 44(4): 553-579

Ó hlfearnáin, Tadhg. 2011. 'Breton language maintenance and regeneration in regional education policy' in Catrin Norrby \& John Hajek (eds.) Uniformity and diversity in language policy: Global perspectives (Bristol: Multilingual Matters) 93-108

Palosaari, Naomi \& Lyle Campbell. 2011. 'Structural aspects of language endangerment' in Peter K. Austin \& Julia Sallabank (eds.) The Cambridge Handbook of Endangered Languages (Cambridge: Cambridge University Press) 100-119

Peperkamp, Sharon. 2004. 'Lexical exceptions in stress systems: arguments from early language acquisition and adult speech perception' Language 80(1): 98-126

Peperkamp, Sharon, Inga Vendelin \& Emmanuel Dupoux. 2010. 'Perception of predictable stress: A cross-linguistic investigation' Journal of Phonetics 38(3): 422-430

Piette, J. R. F. . 1973. French Loanwords in Middle Breton (Cardiff: University of Wales Press)

Press, J. Ian. 1986. A Grammar of Modern Breton (Berlin: Mouton de Gruyter)

Press, J. Ian. 2009. 'Breton' in Martin J. Ball \& Nicole Müller (eds.) The Celtic Languages (London; New York: Routledge) 427-487

Rice, Keren. 2014. 'Convergence of prominence systems?' in Harry van der Hulst (ed.) Word stress: theoretical and typological issues (Cambridge: Cambridge University Press) 194-227

Scullen, Mary Ellen. 1997. French prosodic morphology: a unified account (Bloomington, Ind.: Indiana University Linguistic Club Publications)

Sichel-Bazin, Rafèu, Carolin Buthke \& Trudel Meisenburg. 2015. 'Prosody in Language Contact: Occitan and French' in Elisabeth Delais-Roussarie, Mathieu Avanzi \& Sophie Herment (eds.) Prosody and language in contact: L2 acquisition, attrition and languages in multilingual situations (Berlin: Springer) 71-99

Sinou, André. 1999. Le breton de Léchiagat: quelques aspects du système phonologique du parler breton de Léchiagat (Finistère) (Lesneven: Hor Yezh) 
Smith-Christmas, Cassie, Noel Ó Murchadha, Michael Hornsby \& Máiréad Moriarty. (eds.) 2018. New speakers of minority languages: linguistic ideologies and practices (Basingstoke: Palgrave Macmillan)

Sommerfelt, Alf. 1921. Le Breton parlé à Saint-Pol-de-Léon (Paris: Champion)

Ternes, Elmar. 1992. 'The Breton Language' in Donald MacAulay (ed.) The Celtic Languages (Cambridge: Cambridge University Press) 371-452

Thomason, Sarah G. \& Terrence Kaufman. 1988. Language contact, creolization and genetic linguistics (Berkeley: University of California Press)

Timm, Lenora A. 1984. 'The segmental phonology of Carhaisien Breton' Zeitschrift für celtische Philologie 40(1): 118-192 